NBER WORKING PAPER SERIES

\title{
POST-RETIREMENT INCREASES IN \\ PENSIONS IN THE 1980S: \\ DID PLAN FINANCES MATTER?
}

Steven G. Allen

Robert L. Clark

Ann A. McDermed

Working Paper No. 4413

\section{NATIONAL BUREAU OF ECONOMIC RESEARCH 1050 Massachusetts Avenue \\ Cambridge, MA 02138 \\ August 1993}

The Department of Labor supported this research under Contract No. J-9-P-80100. Thanks go to Melinda Holstein for research assistance and to Olivia Mitchell, Michael Curme, and participants in various workshops and conferences for helpful comments. David McCarthy and Daniel Beller of the Department of Labor provided useful comments throughout this project and facilitated the data analysis. Any opinions, findings, or conclusions expressed here are those of the authors and do not necessarily reflect the views of the Department of Labor. This paper is part of NBER's research programs in Aging and Labor Economics. Any opinions expressed are those of the authors and not those of the National Bureau of Economic Research. 
NBER Working Paper \#4413

August 1993

\section{POST-RETIREMENT INCREASES IN \\ PENSIONS IN THE 1980S: \\ DID PLAN FINANCES MATTER?}

\section{ABSTRACT}

Many firms give post-retirement increases in pension benefits to retirees even though the pension contract does not require such increases. A leading explanation of this behavior is that benefit increases are part of an implicit contract where retirees accept lower initial benefits in return for the option of receiving a share of the plan's financial returns above the risk-free rate. The paper reports mixed evidence on the linkage between the financial performance of pension plans and post-retirement increases. Between 1980 and 1985, benefit increases were larger in plans with high funding ratios and lofty rates of return. However, the practice of giving post-retirement increases became much less widespread in the 1980 s, despite dramatically improved financial performances across all pension plans.

Steven G. Allen

Depts. of Economics \&

Business Management

North Carolina State Univ.

Box 7229

Raleigh, NC 27695

and NBER

Ann A. McDermed

Dept. of Business Management

North Carolina State University

Box 7229

Raleigh, NC 27695
Robert L. Clark

Depts. of Economics \&

Business Management

North Carolina State Univ.

Box 7229

Raleigh, NC 27695 


\section{INTRODUCTION}

In the presence of inflation, retirement benefits decline in real value unless they are periodically increased. The proportion of participants in defined-benefit plans that were in plans with provisions for automatic cost-of-living adjustments in 1986 was a mere 3 percent. ${ }^{1}$ Unless benefit increases given on an ad hoc basis are widespread and sizable, inflation constitutes a significant threat to the economic well-being of retirees. ${ }^{2}$

Allen, Clark, and Sumner $(1984,1986)$, henceforth denoted as ACS, found that most retirees received at least one increase in their benefits between 1973 and 1979. This behavior by plan sponsors is anomalous for a very simple reason -- there was no explicit contract stipulating these payments.

Why would pension plans transfer large amounts of money to beneficiaries when they were under no legal obligation to do so?

${ }^{1}$ This calculation is based on the public use tape of the 1986 Employee Benefit Survey, a data set described in more detail below.

${ }^{2}$ Although inflation was lower in the 1980s than the previous decade, even low rates of inflation can have a serious effect on the purchasing power of the elderly if pension benefits are not adjusted. Between 1979 and 1989, prices rose at an annual rate of 5.5 percent. At this rate the purchasing power of a $\$ 1000$ monthly pension will be only $\$ 585$ ten years later if no post-retirement increases are provided. 
Pesando (1984) introduced an implicit contract model that explains this behavior in terms of risk-sharing. Pesando showed that, under reasonable assumptions, workers would be willing to pay (in the form of reduced initial benefits at retirement) for the option of sharing any gains if the actual rate of return on plan assets turns out to be greater (as it should on average) than the risk-free rate. In this framework one would expect the plan's financial health to affect the incidence and magnitude of benefit increases over reasonable periods of time. For example, a pension fund that had assets in excess of liabilities would be expected to award more increases than an underfunded plan.

ACS (1986) examined the conditions under which such a contract is optimal. The most important factor is the ability of the firm to credibly commit itself to the implicit contract. This is more likely for large firms, which have lower odds of going out of business and face a greater loss of reputation than small firms because of their greater visibility, and for firms covered by collective bargaining agreements, where workers and retirees have more influence in compensation decisions.

This paper examines the linkage between the financial performance of a pension plan and post-retirement increases in benefits 
in two ways. At the macro level, one would expect that if plan finances were the dominant variable influencing the practice of postretirement adjustments, then the increased rates of return and improved funding ratios in the 1980 s would have caused such adjustments to be more widespread. ${ }^{3}$ Comparisons of post-retirement adjustments in the 1970s and 1980s using the Employee Benefit Survey (EBS) are reported in Section II. Although there are problems with data comparability across the two periods and the inability to make the standard ceteris paribus assumptions, the results show that despite improved financial conditions, the practice of providing post-retirement adjustments has become much less widespread.

The main innovation of this study is an examination in Section III, using micro data on defined-benefit plans, of how benefit increases between 1981 and 1985 are related to two key indicators of a plan's financial condition: the funding ratio and the rate of return to the plan's

${ }^{3}$ The rate of return in the 1970 s for large plans was 58 percent. The most comparable estimate for 1980-86 is based on 5500 data and shows a 150 percent increase. Both estimates are obtained from U.S. Department of Labor (1989). The mean funding ratios increased from 0.93 in 1981 to 1.33 in 1987, according to Applebaum (1992). 
portfolio in $1985 .{ }^{4}$ The Bureau of Labor Statistics in cooperation with the Pension and Welfare Benefit Administration of the U.S. Department of Labor merged the 1986 EBS with 1985 Form 5500 files. The addition of the Form 5500 information provides data on the financial status of the plans. ${ }^{5}$ The main results from this analysis are that financial variables are not very helpful in explaining which firms gave increases, but within the set of plans that gave increases, they are strongly related to the magnitude of the increase.

The final section of the paper addresses the apparent contradiction between the macro and micro results. Post-retirement adjustments could become less widespread, despite improved financial conditions, if (1) the incentives to renege on implicit contracts have changed or (2) post-retirement increases represent altruistic behavior, not an implicit contract.

${ }^{4}$ In defined contribution plans, the worker/retiree is typically viewed as the owner of the plan's assets and directly receives the gains from higher than expected rates of return. For this and other reasons, beneficiaries of defined contribution plans typically are not thought to be part of implicit contracts.

${ }^{\text {ST }}$ To maintain confidentiality of the EBS respondents, this merged data file was not released directly to the investigators. Instead the investigators prepared computer programs that were then executed in Washington by BLS staff. 


\section{WHAT HAPPENED IN THE 1980S?}

Trends in post-retirement increases can be examined from various BLS bulletins describing the results from the 1983 to 1989 EBS. Each of these surveys contained information on the frequency and magnitude of post-retirement increases over a five-year period. Table 1 indicates the percentage of full-time pension participants in defined-benefit plans granting ad hoc benefit increases during the five years preceding the various surveys. These data show that the proportion of participants in plans awarding at least one increase in the five year period declined from 51 percent between 1977 and 1982 to 41 percent between 1979 and 1984 and further to only 22 percent between 1983 and 1988.

Benefit increases also were given less frequently. Consider only those participants who received an increase. Between 1977 and 1982,61 percent of these participants were in plans that granted two or more increases. From 1983 to 1988 , only 46 percent of these participants were in plans that awarded two or more increases.

Did pension benefit increases in the 1980 s provide the same level of protection against inflation as benefit increases in the 1970s? 
ACS found that between 1973 and 1979 the CPI increased by 63 percent and 75 percent of all beneficiaries in defined benefit plans received at least one increase. Across all beneficiaries, the average benefit increased by 24 percent. The most comparable period in the EBS studies is 1977 to 1982 , when the CPI increased by 57 percent and 51 percent of the participants were in plans that gave increases. The EBS reports six hypothetical cases of how much benefits increased, assuming at least one benefit increase was given. The average increase in these cases was 21 percent. Using this as an estimate of the average increase in benefits for beneficiaries who received at least one increase, the participant-weighted estimate of the expected increase in benefits for this period is 11 percent, well below the ACS estimate. The corresponding increase in benefits for $1983-88$ is 2 percent. Estimates for other periods are reported in Table $2 .^{6}$ Further evidence that

There are two important differences between the methodology used to generate these results and those obtained by ACS. First, the sample frame and the related weighting scheme in the EBS data are based on pension plan participants, whereas the ACS results pertain to a sample of pension beneficiaries. Although one would expect some correlation between these two variables, they can be quite different because of such factors as the amount of time the plan has been in existence, changes in the rules for plan participation or benefit eligibility, longevity of beneficiaries, employment growth, and plan terminations.

The merged EBS- 5500 data set contains information on the number of beneficiaries as well as the number of participants in each plan. This 
benefit increases were smaller in the 1980s is reported in Gustman and Steinmeier (1991).

Among plans that gave benefit increases, the magnitude of the average increase declined throughout the 1980s, along with inflation. One indicator of how benefit increases compared to inflation is the indexation rate, the ratio of benefit increases to inflation. As shown in Row 5 of Table 2, the indexation rate for plans that gave increases increased through most of the 1980s, rising from 37 percent for 197782 to 89 percent in $1980-85$. Although it fell to 47 percent in $1983-88$, it remained higher than at the beginning of the decade.

Another indicator of how benefit increases compared to inflation for plans giving increases is the decline in real benefits, shown

was used to estimate the number of beneficiaries in these plans, as well as the number in plans that gave increases. These estimates indicate that 47.8 percent of the beneficiaries were in plans that granted at least one increase between 1980 and 1985. This estimate, although larger than the 35 percent level reported for the same period in Table 1 , is still considerably smaller than the ACS estimates.

Second, the ACS sample included plans from all size categories, whereas the EBS focuses on larger firms. Because plan size tends to be correlated with the incidence and magnitude of benefit increases, the omission of small firms in the EBS sample should bias the estimates of benefit increases in Table 2 upward relative to the ACS estimates. Despite this bias, the estimates in Table 2 for 1977-82 are considerably smaller than the ACS estimates. 
in Row 7 of Table 2. The effect of inflation on real benefits in these plans was less severe by the end of the 1980s. Real benefits in plans giving increases declined by 8 percent in 1983-88, much lower than the 23 percent rate for $1977-82$. The rate of decrease in real benefits in these plans slowed because of both greater indexation rates and lower inflation.

The effect of inflation on the average beneficiary depends on the likelihood of getting a benefit increase and, if one is given, the magnitude of the increase relative to inflation. In the 1980s, these factors worked in opposite directions. While relatively fewer plans provided increases, among plans that did, the magnitude of the increase grew relative to inflation. Combining both factors, Row 6 of Table 2 shows that by the end of the decade the average increase in benefits across all plans had fallen relative to inflation. The indexation rate across all plans fell from 19 percent in 1977-82 to 10 percent in 198388.

The rate of decrease in real benefits declined, but this was caused by a steep reduction in inflation overcoming the impact of smaller benefit increases (and lower indexation rates). This can be seen by comparing the first and last columns of Table 2 . The rate of 
decrease in real benefits dropped from 29 to 14 percent as inflation fell from 57 to 19 percent, offsetting the decline in nominal benefit growth from 11 to 2 percent. If inflation had not dropped in the 1980s, the lower indexation rate would have resulted in an even more severe drop in the standard of living of pension beneficiaries than in the 1970s.

The improved performance of the stock market in the 1980s would lead one to believe that more firms would be giving benefit increases than in the 1970s if financial performance of the plan played a dominant role in determining the incidence and magnitude of benefit increases. This is clearly not the case either in the aggregate results shown in Tables 1 and 2, or in the more disaggregated breakdown by occupation, employer size, and industry reported in Allen, Clark, and McDermed (1991). The only evidence that beneficiaries received some share of the increased rates of return in the 1980s is the increased indexation rate among plans that gave at least one increase.

Even though the aggregate trends in post-retirement increases are not positively related to the financial performance of pension plans, there is still the question of whether the incidence or magnitude of benefit increases across a sample of plans is related to financial variables. The next section addresses this issue. 


\section{DETERMINANTS OF BENEFIT INCREASES}

The 1986 EBS contains information on the incidence and provisions of employee benefit plans in medium and large firms. It includes data representing 21.3 million full-time employees in private industries in the United States. The file identifies three occupational groups; eight industrial categories; four regions; age of the plan; and whether the plan sponsor is a single employer or a multi-employer association.

Among medium and large firms, 76 percent of employees were covered by a defined-benefit plan. The EBS indicates whether these plans awarded post-retirement increases in benefits in each year from 1981 to 1985 . For each benefit increase given, the EBS reports the formula determining its magnitude. Using these data, the investigators determined the incidence of increases between 1980 and 1985 and the magnitude of these increases for retirees of particular characteristics.

Table 3 reports the sample means for the 1986 EBS public use tape and for the merged EBS-5500 file. ${ }^{7}$ In terms of sample

${ }^{7}$ The sample size of the merged file is considerably smaller than that of the public use tape because some plans appear more than once in the EBS file (e.g., if the same plan covers production and technical workers) and 
characteristics, both files are quite similar. Approximately half of the participants in the sample are in plans for production workers; professional/administrative and technical/clerical participants each account for about one quarter of the sample. The manufacturing sector dominates the sample with 55 percent of the participants. Just over one third of the sample consists of participants in firms with 2,500 or more workers, whereas firms with 500 to 999 employees and firms with 1,000 to 2,499 each account for nearly 20 percent of the sample. The EBS is almost entirely composed of single employer plans.

Four other variables from the EBS file are used in the results below. Funding arrangements are a potential indicator of the existence of an implicit contract for post-retirement increases. In plans funded entirely through insurance companies, it is quite likely that the arrangement is nothing more than an explicit annuity contract between the plan and its beneficiaries.

ACS (1986) showed that plans covered by collective bargaining agreements are much more likely to give benefit increases than other plans. There is no information about collective bargaining coverage on 
the EBS. The best available proxy is information about the benefit formula. In union plans the benefit formula is usually either a flat benefit or a flat benefit related to years of service. Further, most participants in plans using this benefit formula are covered by collective bargaining agreements. ${ }^{8}$

ACS also showed that benefit increases were positively correlated with the number of beneficiaries in a plan. This could reflect economies of scale in plan administration, the tendency for large employers to sponsor large plans, or both. Five binary indicators of the number of employees in the sponsoring firm are included in all specifications reported below.

Lastly, a control for whether the plan has an automatic cost-ofliving-adjustment is included in the model. Plans with automatic adjustments are not likely to give ad hoc adjustments as well.

Two measures of the plan's financial performance were derived from the 5500 schedule: the estimated rate of return and the termination

${ }^{8}$ In 1977,72 percent of the participants in collectively bargained plans had flat benefit formulas. Of all participants in plans with this type of formula for whom union status was identified, 80 percent were in union plans. These calculations are based on Kotlikoff and Smith (1983), Table 4.5 .3 , p. 218. 
funding ratio. ${ }^{9}$ In thory, financial performance determines both the incidence and the magnitude of a benefit increase. The transition from theory to empirics is far from straightforward in this case. One would expect a decision lag between the arrival of good financial news to the delivery of larger checks to beneficiaries. In addition, transactions costs dictate that benefit increases be given on a periodic basis, usually no more than once a year. Most plans give increases much less frequently than that, as shown in Table 1 . Thus, one would need data on both financial performance and post-retirement increases over a

These variables are defined in the following way:

a) ESTIMATED RATE OF RETURN. Net income is defined as the sum of earnings from investments (item number $14 \mathrm{~d}$ on the 5500 form), net realized gain (loss) on sale or exchange of assets (14e), other income (14f), unrealized appreciation (depreciation) of assets (14ni), and net investment gain (loss) from all master trust investments (14nii) less interest expense (14i) and unrealized appreciation (depreciation) of buildings and other depreciable property used in plan operations (13eb minus 13ea if both are greater than zero; zero if either is less than or equal to zero). Investible assets are total assets $(.5 *(13 \mathrm{ha}+13 \mathrm{hb}))$ less net receivables $\left(.5^{*}(13 \mathrm{bva}+13 \mathrm{bvb})\right)$ less the value of buildings used in plan operations $\left(.5^{*}(13 \mathrm{ea}+13 \mathrm{eb})\right)$ less net income. There are no adjustments for administrative expenses for each plan because Form 5500 does not identify all costs of investing. This variable was created by the staff of the Pension and Welfare Benefits Administration, U. S. Department of Labor (PWBA).

b) TERMINATION FUNDING RATIO. This is obtained from Schedule B for Form 5500. It is the ratio of current value of the assets accumulated in the plan as of the beginning of the plan year (6c) to the present value of vested benefits as of the beginning of the plan year (6diii). This variable also was created by the staff of the PWBA. 
number of years in order to test these propositions.

Furthermore, it is unlikely that all defined benefit plans have implicit contracts requiring post-retirement benefit increases. In the data it is not possible to differentiate between plans with such contracts and plans without them. Therefore, it is difficult to untangle the impact of financial performance on the incidence of benefit increases. The estimation tests for both the existence of an implicit contract and the importance of financial variables in determining the incidence of increases. Over a sufficiently long time period, one would expect all plans with implicit contracts to give at least one increase, except perhaps for a handful of plans with truly abysmal financial results.

The merged EBS-5500 file contains information on benefit increases from 1980 to 1985 , but all financial data pertain to 1985 only. The funding ratio reflects rates of return over the entire five-year period, along with the funding level of the plan in 1980. The rate of return in 1985 is an imperfect signal of rates of return over the entire period, although some autocorrelation is no doubt present because administrative costs and portfolio composition are likely to exhibit some persistence. Because of these flaws, there will be a bias toward finding no relationship between financial performance and benefit increases. 
The average of assets at the beginning and the end of 1985 is used as an indicator of economies of scale in plan administration. Other variables from Form 5500 used in the analysis below include the age of the plan (in years), the year in which the plan became effective, and the ratio of recipients to participants. ${ }^{10}$ This last variable is used as a control for the potential demand for giving post-retirement increases. Plans with large ratios presumably would face more pressure to give increases. This could arise from increased pressure on the firm or the plan's administrators or the greater sensitivity of such firms to their reputations. On the other hand, the "price" of giving an increase is greater in plans with large ratios, thereby reducing the likelihood and the magnitude of an increase.

\section{Who gives increases?}

A logit probability model was estimated to determine the relationship between the probability that a plan gave at least one postretirement increase between 1980 and 1985 and the plan characteristics in the merged EBS-5500 file. Before discussing these results, the

${ }^{10}$ Recipients include retired or separated participants receiving benefits and deceased participants whose beneficiaries are receiving or are entitled to receive benefits. Participants include those who are active in the plan and those who are retired or separated and entitled to receive benefits in the future, as well as recipients. 
functional form for one of the key variables requires explanation. In creating the rate of return variable, the PWBA classified the rate of return as missing for 29 percent of the sample. In most cases this was done because key information was missing from Form 5500, but in a few cases it was done because the estimated rate of return was implausible. Rather than dropping such cases from the sample, the rate of return variable was expressed in categorical form, with one of the categories being that the rate of return was not reported. This procedure retains the valuable information on funding and beneficiaryparticipant ratios, while avoiding possible biases resulting from nonrandom sampling.

Table 4 reports the percentage of participants in plans that gave benefit increases by rate of return. Participants in plans with rates of return of 15 percent or below are much less likely to receive increases than those in other plans. However, after controlling for other factors, the evidence in Table 5 relating rate of return in 1985 to the odds that a plan would give a post-retirement increase is mixed. The derivatives in the third column indicate the difference in the probability of giving a post-retirement increase in 1981-85 between plans in the indicated rate of return category and plans with a rate of return of 10 percent or 
less. Only three percent of all plans fall into the latter category and, other things equal, these plans tend to have higher odds of giving postretirement increases than plans in all but one of the other categories (plans with a rate of return between 16 and 20 percent). One might infer from this result that rate of return is in fact inversely related to the odds of giving an increase, exactly the opposite of what one would expect.

The data do not support such a clean conclusion. Given the imprecision of the estimates, plans in the middle rate of return categories (16 to 20 and 21 to 25 percent) are just as likely to have given benefit increases as plans with rates of return of 10 percent or less. The odds of giving a benefit increase are significantly lower in the 11 to 15 and the above 25 percent categories than in the 10 percent or below category.

This implies a nonlinear, irregular relationship between rates of return in 1985 and the odds of giving a benefit increase in 1980-85. There are more participants in the 11 to 15 percent category than in the 10 percent or below category. The results show that the plans in the former group are much less likely to have given increases than the plans with rates of return between 16 and 25 percent. Given the 
extremely small number of plans in the 10 percent or below category, a more reasonable conclusion would be that the odds of giving a benefit increase actually rise with a plan's rate of return until the rate of return passes 25 percent, after which they fall.

The mixed results for rate of return could be attributed to the use of information for a single year. Information about the plan's financial performance in the late 1970s through 1984 clearly would have been useful. This information is reflected in the funding ratio. Funding ratios reflect the plan's long run financial performance, but they do so imperfectly because many plans funded their benefits on a pay-as-you-go basis until pension reform regulation was passed in 1974. Some severely underfunded plans would presumably be less likely to give post-retirement increases because of their obligation to gradually meet federal funding requirements, whereas in other cases maintaining the implicit contract with participants and beneficiaries would be a higher priority.

There is no relationship between the termination funding ratio and the odds of giving a benefit increase in Table 5. This result should be interpreted with caution, however, because of possible simultaneity between the two variables. The practice of giving post-retirement 
increases throughout the 1970 s and 1980 s reduces the funding ratio somewhat. However, it is quite unlikely that this feedback effect is very large; most underfunded plans got that way from pay-as-you-go funding in previous decades, not through post-retirement increases in the 1980s.

Indicators of the likelihood of the existence of an implicit contract do a much better job in predicting which plans gave increases. There is a large gap in the odds of giving a benefit increase between plans where funding is arranged entirely through an insurance company and plans with other funding arrangements. The probability of being in a plan that granted a benefit increase are 16 percentage points lower in plans funded through insurance companies than in plans funded through trust funds.

Similarly, plans that pay benefits based solely on a flat dollar amount or years of service are 25 percentage points more likely to give increases than plans with earnings-based benefit formulas. This suggests that collective bargaining coverage remains an important predictor of the incidence of benefit increases.

Large plans, whether measured in terms of employer size or net assets, are much more likely to give benefit increases. This result is 
consistent with the ACS studies. Ad hoc benefit increases are very unlikely in plans that already pay automatic increases.

A final factor that enters into the decision to give benefit increases is the ratio of beneficiaries to participants. Despite the higher price of giving increases in plans with high ratios, such plans are much more likely to give benefit increases. This presumably reflects the greater political clout of beneficiaries in such an environment.

Why do benefit increases vary across plans?

Plans use a wide variety of formulas to grant post-retirement increases. Some give a flat amount to all beneficiaries; others make the increase a flat amount for each year of service. Another common practice is to give percentage increases; in many cases the percentage is a function of years retired or years of service. In general, firms offer greater increases to persons who have been retired longer, have lower benefits, and had more years of service.

Our data set does not report characteristics of beneficiaries that would permit calculation of the average benefit increase for each plan. Rather than focus on a single "typical" beneficiary, benefit increases were calculated under 36 possible scenarios for each plan granting at least one increase in the matched EBS-5500 sample. This approach 
allows the impact of financial variables on the magnitude of postretirement increases to vary by year of retirement, initial pension benefit, and years of service. The cases correspond to four possible retirement dates $(1965,1970,1975,1980)$, three different levels of monthly 1980 benefits ( $\$ 250, \$ 500, \$ 1000)$, and three different levels of years of service $(10,20,30)$. For each scenario, benefit increases were regressed against various plan characteristics from the EBS data and plan financial performance variables from the 5500 data. The results of this analysis are summarized in Table 6 and reported in more detail in Appendix Tables A1 through A4. Sample sizes vary across the appendix tables because of restrictions on eligibility for benefit increases and differences in the age of the plans. All samples are restricted to plans that gave at least one increase.

The key result across all of these tables is that the magnitude of benefit increases given by plans is related to financial variables. This relationship does not hold in every specification for every financial variable. Nonetheless the weight of the evidence indicates that plans with higher rates of return and healthier funding ratios gave larger increases than plans that had lower rates of return and funding ratios well below one. 
Consider the case of a person who retired in 1980 with 20 years of service and a monthly 1980 pension of $\$ 250$ (Table A4, column 2). If that person were in a plan that had a rate of return above 20 percent, the monthly benefit increase would be $\$ 25$ larger than the increase for persons in plans with a smaller rate of return. Given that the average increase was $\$ 37$ in this category, this is a very large difference.

The relative impact of rate of return on benefit increases is much greater for retirees with low benefit levels. For a 1970 retiree (Table A2) with 20 years of service, the coefficient corresponding to a 21 to 25 percent rate of return indicates that a person receiving $\$ 250$ a month in 1980 received a benefit increase of $\$ 25$, whereas the absolute dollar amount of the increase is only slightly larger ( $\$ 30$ and $\$ 39)$ for those with 1980 benefits of $\$ 500$ or $\$ 1000$. In the specifications based on a 1980 benefit of $\$ 250$, seven of 12 show a positive and statistically significant relationship between the rate of return and benefit increases, in contrast to four of 12 for 1980 benefits of $\$ 500$ and none of 12 for a 1980 benefit of $\$ 1000$.

The relationship between rate of return and benefit increases becomes stronger for those with greater seniority. In the specifications 
based on 30 years of service, seven of 12 show a positive relationship between rate of return and the size of the benefit increase, in contrast to four of 12 for 20 years of service and none of 12 for 10 years of service.

In 30 out of 36 cases there is a positive and statistically significant, positive relationship between the funding ratio and the magnitude of benefit increases, a further indication that the financial health of a plan influences decisions on post-retirement increases. However, the magnitude of this effect is rather small. A 50 percentage point change in the funding ratio, a fluctuation that amounts to tens of millions of dollars for many plans, is associated with a monthly benefit increase of 7 percent for a 1970 retiree with 20 years of service and a 1980 pension of $\$ 500$ per month.

In all but one of the cases, the magnitude of benefit increases is smaller in plans with a large ratio of beneficiaries to participants. This is consistent with an interpretation of this variable as reflecting the cost of giving an increase. This result, combined with the strong positive correlation between this ratio and the odds that a plan will give an increase in Table 5, indicates that firms with high ratios of beneficiaries to participants apparently compensate for the greater 
likelihood of increases by giving smaller increases.

Plans funded jointly through trust funds and insurance companies consistently tend to give smaller increases than plans funded solely through either mechanism. For 1965 retirees, benefit increases in plans funded wholly through insurance companies are actually larger than those funded wholly through trust funds. This result should be interpreted with caution, however, because very few plans funded wholly through insurance companies gave benefit increases. The main effect of funding arrangements is on the incidence of benefit increases, rather than their magnitude.

Larger plans, whether size is indicated either by net assets or number of employees in the covered establishment, gave larger increases than smaller plans. The coefficient of the proxy for collective bargaining coverage (benefit formula based on a flat dollar amount) was negative and statistically significant in almost all specifications. In a bargaining environment marked by wage and benefit concessions, unions apparently have been successful in maintaining the practice of giving benefit increases, but have had to accept cutbacks in their magnitude. 


\section{CONCLUDING REMARKS}

The findings of our research provide mixed support for the theory that the financial status of the plan is a key determinant of postretirement increases. Despite increased rates of return for most pension plans, the odds that a beneficiary of a defined benefit pension plan will receive an increase in his benefit amount are much lower today than they were 10 to 15 years ago. However, financial variables do help explain the magnitude of benefit increases within the set of plans that provided them. Better funded plans gave larger post-retirement increases than underfunded plans; benefit increases were also larger in plans with high rates of return.

The weak relationship between financial variables and the odds of giving an increase is not especially surprising. Such a relationship is expected only when there is an implicit contract relating the two variables. Such a contract is clearly not a part of all pension plans. If one were able to identify which plans contained such a contract, the relationship between financial variables and the incidence of benefit increases would be much stronger. It is also likely that, over a five year period, all plans with such an implicit contract would have at least 
one increase.

The central issue that deserves further attention is why did fewer plans give post-retirement increases in the 1980 s. The results of this study do not deliver a definitive answer, but they narrow the range of possibilities.

The implicit contract model predicts a decline in post-retirement adjustments if there is a reduction in rates of return, a decrease in the market share of firms that provide implicit contracts, or an increased incentive to renege on the contract. The first two possibilities can be flatly rejected. Rates of return for pension plans were much greater in the 1980 s than in the 1970s. For the second possibility to be true, there must be a decline in firm size or a change in occupational or industrial structure. A simple "shift in shares" argument does not wash, however, because in all categories there were sizable drops in the percentage of participants in plans that gave an increase between 1980 and 1985. For instance, among the set of plans sponsored by firms with 2500 or more employees, the participant-weighted share of plans that gave at least one increase dropped from 38 percent in 1981 to 24 percent in 1985. A similar pattern prevails within all major industrial and occupational categories, as shown in Allen, Clark, and McDermed 
(1992).

The third possibility remains intriguing. Faced with the prospect of concession bargaining, have unions sacrificed the interests of retirees in return for wage or job security for workers? The evidence in Table 5 for the union proxy suggests otherwise but direct evidence on post-retirement increases by collective bargaining coverage would be useful to have.

More critically, there is the question of whether firms have become more likely to break implicit contracts, especially through terminating their pension plans. It would be informative to know if firms involved in takeovers, either as predator or prey, have become more likely to reduce post-retirement increases than other firms. If many firms financed post-retirement adjustments in the 1970 s through excess assets, these same assets could have been used in the turbulent financial markets of the 1980 s to take a company private or to buy another company. In the 1980 s, reduced union clout, along with corporate restructuring (as noted by Shleifer and Summers (1988)), could have increased the incentive to renege on an implicit pension contract, thereby reducing the incidence of benefit increases. These issues could be examined by focusing on single employer plans and 
comparing (1) plans sponsored by firms that were terminated (or involved in mergers or takeovers) to plans sponsored by all other firms or (2) benefit increases for a common set of beneficiaries before and after a termination or takeover.

The penalty for reneging on an implicit contract is the loss of one's reputation in the labor market. In the 1970s, when inflation was quite high, firms perceived this cost to be much greater than in the 1980s, when inflation had fallen to three to four percent and was publicly viewed as less damaging to the economic welfare of beneficiaries. This reduction in the cost of not giving post-retirement increases could be another explanation of why fewer increases were given in the 1980s.

The penalty for reneging on an implicit contract is the loss of one's reputation in the labor market. In the 1970s, when inflation was quite high, firms perceived this cost to be much greater than in the 1980 s, when inflation had fallen to three to four percent and was publicly viewed as less damaging to the economic welfare of beneficiaries. This reduction in the cost of not giving post-retirement increases could be another explanation of why fewer increases were given in the 1980s. 
A final possibility is that post-retirement increases represent a form of purely altruistic behavior. In this view, these increases are literally a transfer from stockholders, workers and new retirees to those who are already retired. Assuming that the welfare of the potential recipient plays an important role in the decision to engage in altruistic behavior, such transfers are more likely to take place in a period of high inflation such as the 1970s.

If post-retirement increases are mainly a form of altruistic behavior, then the decreased odds of granting an increase must result from either reduced income of the giver or increased income of the receiver. The evidence on rates of return is sufficient to reject the first factor. As for the second, it would be useful to explore post-retirement increases in the 1950s and 1960s, a time of relatively low inflation. If benefit increases did not become widespread until the inflationary 1970s, this explanation would have some credibility. On the other hand, evidence that benefit increases for retirees were already common before the 1970s would lead one to reject the altruism model altogether as a candidate for explaining increase patterns. 


\section{REFERENCES}

Allen, Steven G; Clark, Robert L.; and McDermed, Ann A., "PostRetirement Benefit Increases in the 1980s," in Trends in Pensions 1992, Washington: U.S. Government Printing Office, 1992, pp. 319-339.

Allen, Steven G.; Clark, Robert L.; and Sumner, Daniel A., "A Comparison of Pension Benefit Increases with Inflation," Monthly Labor Review 107 (May 1984): 42-46.

, "Post-Retirement Adjustments of Pension Benefits," Journal of Human Resources 21 (Winter 1986): 118-137.

Applebaum, Joseph, "Trends in Actuarial Assumptions, Cost Methods, and Funded Status of Defined Benefit Plans," in Trends in Pensions 1992, Washington: U.S. Government Printing Office, 1992, pp. 509-529.

Gustman, Alan L., and Steinmeier, Thomas L., "Pension COLAs," NBER Working Paper No. 3908, November 1991.

Kotlikoff, Laurence J., and Smith, Daniel E., Pensions in the American Economy (Chicago: University of Chicago Press, 1983).

Pesando, James E., "Employee Valuation of Pension Claims and the Impact of Indexing Alternatives," Economic Inquiry 22 (January 1984): 1-17.

Shleifer, Andrei; and Summers, Lawrence H., "Breach of Trust in Hostile Takeovers, in Corporate Takeovers: Causes and Consequences, edited by Alan Auerbach (Chicago: University of Chicago Press, 1988).

U.S. Department of Labor, Pension and Welfare Benefits Administration, Trends in Pensions, 1989. 


\section{Table 1}

Percent of Full-Time Pension Participants in Plans

Granting Ad Hoc Post-Retirement Benefit Increase日

\begin{tabular}{|c|c|c|c|c|c|c|}
\hline $\begin{array}{c}\text { Incidence of } \\
\text { Benefit Increases }\end{array}$ & $1977-82$ & $1978-83$ & $1979-84$ & $1980-85$ & $1982-87^{\circ}$ & $1983-88^{\circ}$ \\
\hline $\begin{array}{l}\text { At least one } \\
\text { increase }\end{array}$ & 51 & 47 & 41 & 35 & 26 & 22 \\
\hline \multicolumn{7}{|c|}{$\begin{array}{l}\text { Participants with } \\
\text { at least one } \\
\text { increase by number } \\
\text { of increases }\end{array}$} \\
\hline $\begin{array}{l}\text { One } \\
\text { Two } \\
\text { Three } \\
\text { Four } \\
\text { Five or more }\end{array}$ & $\begin{array}{r}39 \\
36 \\
9 \\
5 \\
11\end{array}$ & $\begin{array}{r}47 \\
18 \\
16 \\
7 \\
12\end{array}$ & $\begin{array}{r}51 \\
21 \\
10 \\
11 \\
5\end{array}$ & $\begin{array}{r}46 \\
24 \\
9 \\
22 \\
0\end{array}$ & $\begin{array}{r}63 \\
19 \\
15 \\
0 \\
3\end{array}$ & $\begin{array}{r}54 \\
29 \\
13 \\
0 \\
3\end{array}$ \\
\hline
\end{tabular}

The scope of the 1988 and 1989 survey was expanded to include firms with 100 workers or more and representation in the eervice sector was increased. Prior surveys included establighmente with 100 or 250 workers or more depending on the indugtry. Limiting the data to the old scope of the previous surveys, 30 percent of participants received at least one post-retirement annuity increase between 1982 and 1987 .

Source: Bureau of Labor Statistica, Employeg Benefttg in Medium and Large Firmg, various yearg. 
Table 2

Post-retirement Benefit Increases and Inflation, 1977-88

\begin{tabular}{|c|c|c|c|c|c|c|}
\hline Percentage" & $7-82$ & $1978-83$ & $1979-84$ & $1980-85$ & $1982-87$ & $1983-88$ \\
\hline $\begin{array}{l}\text { Participants in plans } \\
\text { giving increases }\end{array}$ & 51 & 47 & 41 & 35 & 26 & 22 \\
\hline $\begin{array}{l}\text { Increase in benefits, } \\
\text { plans giving increases }\end{array}$ & 21 & 18 & 20 & 24 & 14 & 9 \\
\hline $\begin{array}{l}\text { Increase in benefits } \\
\text { all plans }\end{array}$ & 11 & 8 & 8 & 8 & 4 & 2 \\
\hline Increase in $\mathrm{CPI}-\mathrm{U}$ & 57 & 50 & 37 & 27 & 18 & 19 \\
\hline $\begin{array}{l}\text { Indexation rate, } \\
\text { plans giving increases }\end{array}$ & 37 & 36 & 54 & 89 & 78 & 47 \\
\hline $\begin{array}{l}\text { Indexation rate, } \\
\text { all plans }\end{array}$ & 19 & 16 & 22 & 30 & 22 & 10 \\
\hline $\begin{array}{l}\text { Decrease in real benefita, } \\
\text { plans giving fncreases }\end{array}$ & 23 & 21 & 12 & 2 & 3 & 8 \\
\hline $\begin{array}{l}\text { Decrease in real benefita, } \\
\text { all plans }\end{array}$ & 29 & 28 & 21 & 15 & 12 & 14 \\
\hline
\end{tabular}

All percentages are participant weighted.

Sources:

Row 1: Row 1 of Table 1.

Row 2: average Rows 1 to 6 of Table 3 in Allen, Clark, and McDermed.

Row 3: product of Row日 1 and 2, divided by 100 .

Row 4: Row 7 of Table 3 .

Row 5 and 7 : calculated from Rows 2 and 4.

Row 6 and 8: calculated from Rows 3 and 4 . 
Table 3

Digtribution of Participants in Sample Data

\begin{tabular}{|c|c|c|}
\hline & EBS Sample & $\begin{array}{r}\text { Matched } \\
\text { Sample }\end{array}$ \\
\hline $\begin{array}{l}\text { Occupation } \\
\text { Professional \& Administrative } \\
\text { Technical \& clerical } \\
\text { Production }\end{array}$ & $\begin{array}{l}28.3 \\
25.7 \\
45.9\end{array}$ & $\begin{array}{l}29.2 \\
26.4 \\
44.4\end{array}$ \\
\hline $\begin{array}{l}\text { Industry } \\
\text { Mining } \\
\text { Congtruction } \\
\text { Manufacturing } \\
\text { Irangportation } \\
\text { Wholesale Trade } \\
\text { Retail Trade } \\
\text { Finance, Insurance, Real Est. } \\
\text { Services }\end{array}$ & $\begin{array}{r}2.2 \\
0.3 \\
54.9 \\
14.0 \\
3.9 \\
10.2 \\
11.7 \\
2.9\end{array}$ & $\begin{array}{r}1.7 \\
0.3 \\
54.4 \\
14.1 \\
4.2 \\
10.7 \\
11.5 \\
2.9\end{array}$ \\
\hline $\begin{array}{c}\text { Number of Employees } \\
1-99 \\
100=249 \\
250=499 \\
500=999 \\
1000=2499 \\
2500+\end{array}$ & $\begin{array}{r}0.8 \\
8.8 \\
16.3 \\
19.8 \\
20.0 \\
34.4\end{array}$ & $\begin{array}{r}0.8 \\
8.2 \\
16.1 \\
17.5 \\
19.5 \\
37.8\end{array}$ \\
\hline $\begin{array}{l}\text { Employer Entity } \\
\text { Single Employer } \\
\text { Multi-employer }\end{array}$ & $\begin{array}{r}96.0 \\
4.0\end{array}$ & $\begin{array}{r}96.7 \\
3.3\end{array}$ \\
\hline $\begin{array}{l}\text { Region } \\
\text { Northeast } \\
\text { South } \\
\text { North Central } \\
\text { West }\end{array}$ & $\begin{array}{l}22.9 \\
29.9 \\
29.1 \\
18.1\end{array}$ & $\begin{array}{l}23.6 \\
29.8 \\
29.0 \\
17.7\end{array}$ \\
\hline Sample size & 5,707 & $2,444^{\prime}$ \\
\hline
\end{tabular}

The EBS data used for the matching procedure had a sample size of 2,790. Sourceg: Employee Benefit Survey, 1986, and matched 1986 EBS-5500 file. 
Table 4

Percentage of Participants in Plans Providing Poat-retirement Increases By Rate of Return Category

\begin{tabular}{lc} 
Rate of Return & \multicolumn{2}{c}{$\begin{array}{c}\text { Percentage of Participants } \\
\text { inlans with Increages }\end{array}$} \\
Above 258 & 35.2 \\
21 to 258 & 35.6 \\
16 to 208 & 43.6 \\
11 to 158 & 5.3 \\
O to 108 & 21.8 \\
Negative & 0.0 \\
Missing & 35.8 \\
\hline
\end{tabular}

Source: Matched 1986 EBS -5500 file. 
Table 5

Estimated Effects of Retiree and Firm Characteristice on the Probability of Being in a Plan Granting a Post-Retirement Increase 1980-85'

\begin{tabular}{|c|c|c|c|c|}
\hline & $\begin{array}{l}\text { Sample } \\
\text { Mean }\end{array}$ & $\begin{array}{c}\text { Logit } \\
\text { Coefficient }\end{array}$ & $\begin{array}{l}\text { standard } \\
\text { Error }\end{array}$ & $\begin{array}{l}\text { Eetimted } \\
\text { Derivative }\end{array}$ \\
\hline \multicolumn{5}{|l|}{ Rate of Return } \\
\hline $\begin{array}{l}\text { Missing } \\
.11-.15 \\
.16-.20 \\
.21-.25 \\
\text { more than .25 }\end{array}$ & $\begin{array}{l}0.171 \\
0.041 \\
0.144 \\
0.314 \\
0.309\end{array}$ & $\begin{array}{l}-0.034 \\
-1.263 \star \star * \\
0.512 \\
-0.228 \\
-1.016 \star \star *\end{array}$ & $\begin{array}{l}0.364 \\
0.501 \\
0.368 \\
0.348 \\
0.355\end{array}$ & $\begin{array}{r}-0.008 \\
-0.223 \\
0.121 \\
-0.051 \\
-0.214\end{array}$ \\
\hline Funding Ratio (100's) & 0.231 & 0.032 & 0.025 & 0.007 \\
\hline $\begin{array}{l}\text { Ratio of Recipients to } \\
\text { Participants }\end{array}$ & 0.165 & $1.733 \star \star \star$ & 0.559 & 0.394 \\
\hline \multicolumn{5}{|l|}{ Fund Arrangement } \\
\hline $\begin{array}{l}\text { Insurance } \\
\text { Insurance \& Trusts, Other }\end{array}$ & $\begin{array}{l}0.085 \\
0.141\end{array}$ & $\begin{array}{l}-0.796 * * * \\
0.263\end{array}$ & $\begin{array}{l}0.293 \\
0.188\end{array}$ & $\begin{array}{r}-0.159 \\
0.061\end{array}$ \\
\hline \multicolumn{5}{|l|}{ Formula Type } \\
\hline $\begin{array}{l}\text { Dollar Amount Formula } \\
\text { Other }\end{array}$ & $\begin{array}{l}0.276 \\
0.020\end{array}$ & $\begin{array}{l}1.065 \star \star \star \\
-0.947 \star\end{array}$ & $\begin{array}{l}0.178 \\
0.511\end{array}$ & $\begin{array}{r}0.251 \\
-0.178\end{array}$ \\
\hline \multicolumn{5}{|l|}{ Number of Employees } \\
\hline $\begin{array}{r}1=99 \\
100=249 \\
250=499 \\
500=999 \\
1000=2499\end{array}$ & $\begin{array}{l}0.007 \\
0.078 \\
0.155 \\
0.165 \\
0.207\end{array}$ & $\begin{array}{l}0.278 \\
-1.057^{\star \star \star} \\
-0.548^{\star \star} \\
-0.166 \\
-0.146\end{array}$ & $\begin{array}{l}0.387 \\
0.212 \\
0.178 \\
0.183 \\
0.171\end{array}$ & $\begin{array}{r}0.065 \\
-0.200 \\
-0.116 \\
-0.037 \\
-0.033\end{array}$ \\
\hline Net Asseta (millions) & 0.212 & $0.647 * \star \star$ & 0.200 & 0.147 \\
\hline $\begin{array}{l}\text { Automatic cost of Living } \\
\text { Adjustment }\end{array}$ & 0.033 & $-2.094 \star \star \star$ & 0.510 & -0.299 \\
\hline $\begin{array}{l}\text { Sample Size } \\
\text { Likelihood Ratio }\end{array}$ & & $\begin{array}{r}2020 \\
1937.49\end{array}$ & & \\
\hline
\end{tabular}

The following variables were also included: induatry (6 binary variables), occupation ( 2 binary variables, columns 1 and 2 only), region ( 3 binary variables), multi-employer status (column 1 only), age of plan, and year plan became effective ( 5 binary variables).

The derivative of the probability of giving an increase evaluated at the sample means.

* Statistically different from zero at that the .10 confidence level.

** Statistically different from zero at that the .05 confidence level.

*** Statistically different from zero at that the .01 confidence level.

Source: Matched 1986 EBS-5500 file. 
Table 6

Sumary of Estimates of Plan Financial Characteristics on the Magnitude of Post-Retirement Increageg 1980-85.

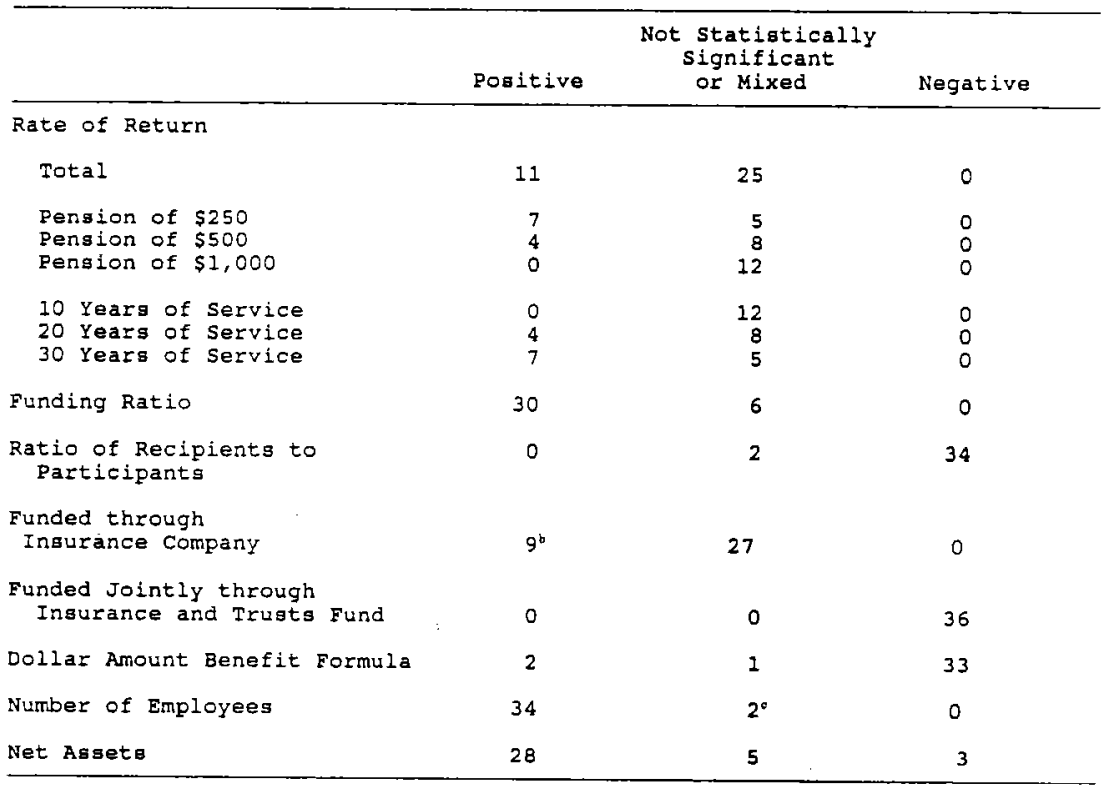

"Samples are restricted to plans that gave at least one increase.

bAll of these caseg represent 1965 retirees.

The pattern here is mixed. Plans with 1-99 employees gave larger increases than plans with 1000-2499 employees, whereas plans with 500-999 employees gave smaller increases than plang with 1000-2499 employees.

Source: Matched 1986 EBS -5500 file. 
Table $\mathbf{A 1}$

Weighted Estimates of the Effects of Retiree and Firm Chorecteristics on Post-Retirement Increases $1980-85$ Participanta Retired in 1965 Receiving increases"

\begin{tabular}{|c|c|c|c|c|c|c|c|c|c|}
\hline & \multicolumn{3}{|c|}{ Pension of $\$ 250$} & \multicolumn{3}{|c|}{ Pension of 5500} & \multicolumn{3}{|c|}{ Pension of $\$ 1,000$} \\
\hline & \multicolumn{3}{|c|}{ Yeers of service } & \multicolumn{3}{|c|}{ Years of Service } & \multicolumn{3}{|c|}{ Years of Service } \\
\hline & 10 & 20 & 30 & 10 & 20 & 30 & 10 & 20 & 30 \\
\hline $\begin{array}{l}\text { Rate of Return } \\
\text { Missing }\end{array}$ & $\begin{array}{c}-0.39 \\
(10.80)\end{array}$ & $\begin{array}{c}10.15 \\
(11.16)\end{array}$ & $\begin{array}{r}18.67 \% \\
(11.32)\end{array}$ & $\begin{array}{l}-12.04 \\
(21.14)\end{array}$ & $\begin{array}{c}-1.58 \\
(20.98)\end{array}$ & $\begin{array}{c}8.83 \\
(21.29)\end{array}$ & $\begin{array}{l}-36.97 \\
(42.47)\end{array}$ & $\begin{array}{l}-26.68 \\
(42.08)\end{array}$ & $\begin{array}{l}-16.44 \\
(42.08)\end{array}$ \\
\hline $.11 \cdot .15$ & $\begin{array}{c}-6.83 \\
(17.61)\end{array}$ & $\begin{array}{c}-9.49 \\
(17.99)\end{array}$ & $\begin{array}{l}-10.95 \\
(18.25)\end{array}$ & $\begin{array}{c}-7.63 \\
(34.07)\end{array}$ & $\begin{array}{l}-10.56 \\
(33.81)\end{array}$ & $\begin{array}{l}-12.76 \\
(34.31)\end{array}$ & $\begin{array}{c}-7.35 \\
(68.45)\end{array}$ & $\begin{array}{l}-10.83 \\
(67.83)\end{array}$ & $\begin{array}{l}-13.57 \\
(67.83)\end{array}$ \\
\hline $.16-.20$ & $\begin{array}{l}-14.52 \\
(11.17)\end{array}$ & $\begin{array}{l}-10.30 \\
(11.54)\end{array}$ & $\begin{array}{c}-6.39 \\
(11.71)\end{array}$ & $\begin{array}{l}-37.71 * \\
(21.86)\end{array}$ & $\begin{array}{l}-33.35 \\
(21.69)\end{array}$ & $\begin{array}{l}-27.90 \\
(22.01)\end{array}$ & $\begin{array}{l}-82.17 \\
(43.91)\end{array}$ & $\begin{array}{l}-77.55^{\star} \\
(43.51)\end{array}$ & $\begin{array}{l}-71.84 * \\
(43.51)\end{array}$ \\
\hline $.21 \cdot .25$ & $\begin{array}{c}-4.18 \\
(10.85)\end{array}$ & $\begin{array}{c}5.71 \\
(11.21)\end{array}$ & $\begin{array}{c}13.70 \\
(11.37)\end{array}$ & $\begin{array}{l}-10.78 \\
(21.23)\end{array}$ & $\begin{array}{c}-0.77 \\
(21.06)\end{array}$ & $\begin{array}{c}9.11 \\
(21.37)\end{array}$ & $\begin{array}{l}.26 .14 \\
(42.64)\end{array}$ & $\begin{array}{l}-15.90 \\
(42.25)\end{array}$ & $\begin{array}{c}-5.78 \\
(42.25)\end{array}$ \\
\hline$>.25$ & $\begin{array}{c}16.59 \\
(11.00)\end{array}$ & $\begin{array}{l}29.66^{\circ} \\
(11.37)\end{array}$ & $\begin{array}{l}35.690 * t \\
(11.54)\end{array}$ & $\begin{array}{c}21.58 \\
(21.52)\end{array}$ & $\begin{array}{c}34.56 \\
(21.36)\end{array}$ & $\begin{array}{l}46.12^{ \pm 1} \\
(21.67)\end{array}$ & $\begin{array}{c}28.35 \\
(43.24)\end{array}$ & $\begin{array}{c}41.16 \\
(42.84)\end{array}$ & $\begin{array}{c}52.56 \\
(42.84)\end{array}$ \\
\hline $\begin{array}{l}\text { Funding Ratio } \\
\text { (times 100) }\end{array}$ & $\begin{array}{l}0.34 * * \\
(0.07)\end{array}$ & $\begin{array}{l}0.23+t t \\
0.08)\end{array}$ & $\begin{array}{l}0.08 \\
0.08)\end{array}$ & $\begin{array}{l}0.80^{* t *} \\
(0.16)\end{array}$ & $\left(\begin{array}{l}0.69 \% \\
0.14)\end{array}\right.$ & $\begin{array}{l}0.58=1 \\
(0.14)\end{array}$ & $\begin{array}{l}1.71 * * * \\
0.29)\end{array}$ & $\begin{array}{l}1.60^{* * * *} \\
(0.28)\end{array}$ & $\begin{array}{l}1.50^{ \pm * *} \\
(0.28)\end{array}$ \\
\hline $\begin{array}{l}\text { Rat io of Recipients } \\
\text { to Participants }\end{array}$ & $\begin{array}{l}-86,30 * \\
(17.80)\end{array}$ & $\begin{array}{l}-92.15 * * t \\
(18.40)\end{array}$ & $\begin{array}{l}-87.89 \text { min } \\
(18.68)\end{array}$ & $\begin{array}{l}-120.6 * 1 \\
(34.84)\end{array}$ & $\begin{array}{l}-127.1)^{* 4 t} \\
(36.57)\end{array}$ & $\begin{array}{l}-132^{* t t} \\
(35.08)\end{array}$ & $\begin{array}{l}-167.7 * t \\
(69.98)\end{array}$ & $\begin{array}{l}-175.7 \pi \\
(69.35)\end{array}$ & $\begin{array}{l}-182^{* \pm \times} \\
(69.35)\end{array}$ \\
\hline $\begin{array}{l}\text { Fund Arrangement } \\
\text { Insurance }\end{array}$ & $\begin{array}{l}48.56 * 1+ \\
(9.72)\end{array}$ & $\begin{array}{l}49.24 * t t \\
(10.05)\end{array}$ & $\begin{array}{l}69.10^{ \pm * t} \\
(10.19)\end{array}$ & $\begin{array}{l}88.57^{\text {mint }} \\
(19.03)\end{array}$ & $\begin{array}{l}88.13^{* * * *} \\
(18.88)\end{array}$ & $\begin{array}{l}88.05^{-1}=1 \\
(19.16)\end{array}$ & $\begin{array}{l}168.57 \div * \\
(38.22)\end{array}$ & $\begin{array}{l}165.93^{t+\hbar} \\
(37.87)\end{array}$ & $\begin{array}{l}163.63^{\star \star \star} \\
(37.87)\end{array}$ \\
\hline $\begin{array}{l}\text { Insurance frusts, } \\
\text { other }\end{array}$ & $\begin{array}{l}-20.72^{* * *} \\
(4.80)\end{array}$ & $\begin{array}{l}-25.53^{* 04} \\
(4.96)\end{array}$ & $\begin{array}{l}-27.48^{* 4 *} \\
(5.04)\end{array}$ & $\begin{array}{l}-41.26^{*} \mathrm{k} \\
(9.40)\end{array}$ & $\begin{array}{l}-46.27 * t * \\
(9.33)\end{array}$ & $\begin{array}{l}-50.43+t t \\
(9.46)\end{array}$ & $\begin{array}{l}-78.44^{* \pi} \\
(18.88)\end{array}$ & $\begin{array}{l}-83.84= \pm \\
(18.71)\end{array}$ & $\begin{array}{l}-88.39^{\star * *} \\
(18.71)\end{array}$ \\
\hline $\begin{array}{l}\text { Benefit Formula } \\
\text { Doltar Amount }\end{array}$ & $\begin{array}{l}-26.17^{+1 *} \\
(4.19)\end{array}$ & $\begin{array}{l}-17.65 * \hbar \\
(4.33)\end{array}$ & $\begin{array}{l}-11.48^{* n+m} \\
(4.40)\end{array}$ & $\begin{array}{l}-66.03^{* * *} \\
(8.20)\end{array}$ & $\begin{array}{l}-57.71^{1 * t} \\
(8.16)\end{array}$ & $\begin{array}{l}+.49 .21 * * \hbar \\
(8.26)\end{array}$ & $\begin{array}{l}-147.4 \pi \pm \\
(16.48)\end{array}$ & $\begin{array}{l}-139.5 * 1= \\
(16.33)\end{array}$ & $\begin{array}{l}-13 \uparrow .3 * \pm * \\
(16.33)\end{array}$ \\
\hline other & $\begin{array}{l}-17.40 \\
(15.52)\end{array}$ & $\begin{array}{l}-22.65 \\
(16.04)\end{array}$ & $\begin{array}{l}-26.65 \\
(16.27)\end{array}$ & $\begin{array}{l}-55.85 \star \\
(30.37)\end{array}$ & $\begin{array}{l}-61.35^{\star \star} \\
(30.16)\end{array}$ & $\begin{array}{l}-65.49 \div \\
(30.58)\end{array}$ & $\begin{array}{l}-131.4^{* *} \\
(61.01)\end{array}$ & $\begin{array}{l}-137.4 \% \\
(60.46)\end{array}$ & $\begin{array}{l}-142^{* *} \\
(60.46)\end{array}$ \\
\hline $\begin{array}{c}\text { Number of Employees } \\
1 \cdot 99\end{array}$ & $\begin{array}{l}-10.12 \\
(17.33)\end{array}$ & $\begin{array}{c}-3.25 \\
(17.91)\end{array}$ & $\begin{array}{c}-2.61 \\
(18.17)\end{array}$ & $\begin{array}{l}-23.19 \\
(33.92)\end{array}$ & $\begin{array}{l}-16.35 \\
(33.66)\end{array}$ & $\begin{array}{l}-17.29 \\
(34.15)\end{array}$ & $\begin{array}{l}-46.94 \\
(68.14)\end{array}$ & $\begin{array}{l}-40.16 \\
(67.52)\end{array}$ & $\begin{array}{l}-41.15 \\
(67.52)\end{array}$ \\
\hline $100-249$ & $\begin{array}{l}-28.33 * 4 * \\
(7.24)\end{array}$ & $\begin{array}{l}-29.08 * 4 * \\
(7.48)\end{array}$ & $\begin{array}{l}-29.346 t= \\
(7.59)\end{array}$ & $\begin{array}{l}-43.23^{+4 t} \\
(14.17)\end{array}$ & $\begin{array}{l}-46.37^{t+t} \\
(16.06)\end{array}$ & $\begin{array}{l}-45.45 * \cdots \\
(16.26)\end{array}$ & $\begin{array}{l}-66.76 \% \\
(28.46)\end{array}$ & $\begin{array}{l}-68.68 * \\
(28.20)\end{array}$ & $\begin{array}{l}-70.55 \pm t \\
(28.20)\end{array}$ \\
\hline $250-499$ & $\begin{array}{l}-11.30^{\star \star} \\
(4.80)\end{array}$ & $\begin{array}{c}-10.43 * * \\
(4.96)\end{array}$ & $\begin{array}{l}-10.80^{* 4} \\
(5.03)\end{array}$ & $\begin{array}{l}-13.85 \\
(9.40)\end{array}$ & $\begin{array}{l}-13.30 \\
(9.33)\end{array}$ & $\begin{array}{l}-14.69 \\
(9.66)\end{array}$ & $\begin{array}{l}-16.64 \\
(18.88)\end{array}$ & $\begin{array}{l}-16.72 \\
(18.71)\end{array}$ & $\begin{array}{l}-18.74 \\
(18.71)\end{array}$ \\
\hline $500=999$ & $\begin{array}{l}-22.07^{4 * 4} \\
(4.59)\end{array}$ & $\begin{array}{l}-26.30^{t 4 t} \\
(4.74)\end{array}$ & $\begin{array}{l}-28.96^{4 * t} \\
(6.81)\end{array}$ & $\begin{array}{l}-32.71^{* 1} \\
(8.97)\end{array}$ & $\begin{array}{l}-37.15^{* \pm *} \\
(8.90)\end{array}$ & $\begin{array}{l}-42.11^{ \pm+1} \\
(9.04)\end{array}$ & $\begin{array}{l}-53.03+t \\
(18.03)\end{array}$ & $\begin{array}{l}-57.90^{+1+t} \\
(17.86)\end{array}$ & $\begin{array}{l}-63.28 \ldots \pi \\
(17.86)\end{array}$ \\
\hline $1000 \cdot 2499$ & $\begin{array}{c}-2.67 \\
(4.18)\end{array}$ & $\begin{array}{c}-5.89 \\
(4.32)\end{array}$ & $\begin{array}{r}-7.29 \\
(4.39)\end{array}$ & $\begin{array}{l}7.33 \\
(8.18)\end{array}$ & $\begin{array}{l}3.87 \\
(8.12)\end{array}$ & $\begin{array}{l}0.56 \\
(8.26)\end{array}$ & $\begin{array}{l}31.69 \\
(16.44)\end{array}$ & $\begin{array}{r}27.76^{*} \\
(16.29)\end{array}$ & $\begin{array}{c}23.96 \\
(16.29)\end{array}$ \\
\hline $\begin{array}{l}\text { Net Assets } \\
\text { (millions) }\end{array}$ & $\begin{array}{r}-7.19 \\
(4.19)\end{array}$ & $\begin{array}{l}0.87 \\
(4.33)\end{array}$ & $\begin{array}{l}16.66^{\#+t} \\
(4.42)\end{array}$ & $\begin{array}{l}-19.93^{\star *} \\
(8.20)\end{array}$ & $\begin{array}{l}-12.05 \\
(8.13)\end{array}$ & $\begin{array}{c}-3.32 \\
(8.25)\end{array}$ & $\begin{array}{l}-42.21 * \\
(16.46)\end{array}$ & $\begin{array}{l}-34.70^{\star \star} \\
(16.31)\end{array}$ & $\begin{array}{l}-26.34 \\
(16.32)\end{array}$ \\
\hline Sample size & 599 & 599 & 597 & 599 & 599 & 599 & 599 & 599 & 599 \\
\hline Adjusted R2 & 0.42 & 0.38 & 0.46 & 0.45 & 0.41 & 0.38 & 0.47 & 0.45 & 0.62 \\
\hline Sample Mean Increase & 48 & 56 & 63 & 83 & 92 & 9 & 153 & 162 & 169 \\
\hline
\end{tabular}

- Standard errors are in parentheses and each equation also contains variables indicating age of the plan, year the plan became effective (5 binary variobles, presence of automatic cost-of-living adjustment, region ( 3 binary variables), occupation ( 2 binary variables), índustry (6 binary variables), and on intercept.

- Statistically different from zero ot that the .10 confidence level.

* Statistically different from zero ot that the .05 confldence level.

*\#* statistically different from zero at that the .09 confidence level.

Source: Matched 1988 EBS-5500 file. 
Toble A2

Weighted Estimates of the Effecte of Retires and Fin Charecteristics on Post-Retirement Increanes 1980-85 Participonte Retired in 1970 Receiving Increases"

\begin{tabular}{|c|c|c|c|c|c|c|c|c|c|}
\hline & \multirow{2}{*}{\multicolumn{3}{|c|}{$\begin{array}{c}\text { Pension of } \$ 250 \\
\text { Years of Service } \\
\end{array}$}} & \multirow{2}{*}{\multicolumn{3}{|c|}{ Pension of $\$ 500$}} & \multirow{2}{*}{\multicolumn{3}{|c|}{$\frac{\text { Pension of } \$ 1,000}{\text { rears of service }}$}} \\
\hline & & & & & & & & & \\
\hline & 10 & 20 & 30 & 10 & 20 & 30 & 10 & 20 & 30 \\
\hline $\begin{array}{l}\text { Rate of Return } \\
\text { Missing }\end{array}$ & $\begin{array}{c}-7.41 \\
(13.42)\end{array}$ & $\begin{array}{c}5.04 \\
(13.41)\end{array}$ & $\begin{array}{c}15.65 \\
(13.19)\end{array}$ & $\begin{array}{l}-26.48 \\
(26.81)\end{array}$ & $\begin{array}{l}-14.11 \\
(26.35)\end{array}$ & $\begin{array}{c}-1.76 \\
(26.26)\end{array}$ & $\begin{array}{l}-65.50 \\
(54.26)\end{array}$ & $\begin{array}{l}-53.27 \\
(53.60)\end{array}$ & $\begin{array}{l}-41.07 \\
(53.22)\end{array}$ \\
\hline $.11 \cdot .15$ & $\begin{array}{c}-0.19 \\
(21.70)\end{array}$ & $\begin{array}{c}-3.37 \\
(21.69)\end{array}$ & $\begin{array}{c}-5.46 \\
(21.33)\end{array}$ & $\begin{array}{c}6.63 \\
(43.35)\end{array}$ & $\begin{array}{c}3.19 \\
(42.61)\end{array}$ & $\begin{array}{c}0.46 \\
(42.45)\end{array}$ & $\begin{array}{c}21.50 \\
(87.74)\end{array}$ & $\begin{array}{c}17.55 \\
(86.67)\end{array}$ & $\begin{array}{c}14.30 \\
(86.06)\end{array}$ \\
\hline $.16-.20$ & $\begin{array}{c}4.87 \\
(13.75)\end{array}$ & $\begin{array}{c}10.96 \\
(13.75)\end{array}$ & $\begin{array}{c}16.69 \\
(13.52)\end{array}$ & $\begin{array}{c}4.43 \\
(27.47)\end{array}$ & $\begin{array}{c}10.61 \\
(27.00)\end{array}$ & $\begin{array}{c}17.73 \\
(26.90)\end{array}$ & $\begin{array}{c}4.21 \\
(55.60)\end{array}$ & $\begin{array}{c}10.56 \\
(54.93)\end{array}$ & $\begin{array}{c}17.86 \\
(54.54)\end{array}$ \\
\hline $.21-.25$ & $\begin{array}{c}10.82 \\
(13.48)\end{array}$ & $\begin{array}{r}24.98 \\
(13.47)\end{array}$ & $\begin{array}{l}36.73^{*+1} \\
(13.25)\end{array}$ & $\begin{array}{c}15.38 \\
(26.93)\end{array}$ & $\begin{array}{l}29.68 \\
(26.47)\end{array}$ & $\begin{array}{r}43.84 * \\
(26.37)\end{array}$ & $\begin{array}{l}24.38 \\
(54.49)\end{array}$ & $\begin{array}{l}38.96 \\
(53.83)\end{array}$ & $\begin{array}{c}53.40 \\
(53.45)\end{array}$ \\
\hline$>.25$ & $\begin{array}{c}-6.34 \\
(13.55)\end{array}$ & $\begin{array}{c}9.81 \\
(13.54)\end{array}$ & $\begin{array}{c}19.79 \\
(13.35)\end{array}$ & $\begin{array}{l}-25.27 \\
(27.06)\end{array}$ & $\begin{array}{c}-9.20 \\
(26.60)\end{array}$ & $\begin{array}{c}5.65 \\
(26.50)\end{array}$ & $\begin{array}{l}-62.75 \\
(54.77)\end{array}$ & $\begin{array}{l}-46.85 \\
(54.11)\end{array}$ & $\begin{array}{l}-32.17 \\
(53.72)\end{array}$ \\
\hline $\begin{array}{l}\text { Funding Ratio } \\
\text { (times 100) }\end{array}$ & $\begin{array}{l}0.35^{\star \hbar *} \\
0.09)\end{array}$ & $\left(\begin{array}{l}0.25^{* * *} \\
0.09)\end{array}\right.$ & $\begin{array}{l}0.13 \\
(0.09)\end{array}$ & $\begin{array}{l}0.83^{* * *} \\
(0.18)\end{array}$ & $\left(\begin{array}{l}0.73^{* * *} \\
0.17)^{*}\end{array}\right.$ & $\begin{array}{l}0.63^{* * *} \\
0.17)\end{array}$ & $\begin{array}{l}1.78^{* k *} \\
(0.36)\end{array}$ & $\begin{array}{l}1.69 * * \\
(0.35)\end{array}$ & $\left(\begin{array}{l}1.59 * \pi * \\
0.35)\end{array}\right.$ \\
\hline $\begin{array}{c}\text { Ratio of Recipients } \\
\text { to Participants }\end{array}$ & $\begin{array}{l}-72.29 * * * \\
(22.01)\end{array}$ & $\begin{array}{l}-72.26^{* k *} \\
(21.99)\end{array}$ & $\begin{array}{l}-61.19 \text { thk } \\
(21.66)\end{array}$ & $\begin{array}{l}-108.5^{t t} \\
(43.96)\end{array}$ & $\begin{array}{l}-100.2 * \\
(43.21)\end{array}$ & $\begin{array}{l}-108.5 * t \\
(43.05)\end{array}$ & $\begin{array}{l}-180.2^{\star \star} \\
(88.97)\end{array}$ & $\begin{array}{l}-182.4 * * \\
(87.89)\end{array}$ & $\begin{array}{l}-183.3 \pm * \\
(87.26)\end{array}$ \\
\hline \multicolumn{10}{|l|}{ Fund Arrangenent } \\
\hline Insurence & $\begin{array}{r}21.75^{\star} \\
(12.07)\end{array}$ & $\begin{array}{r}21.87 \\
(12.06)\end{array}$ & $\begin{array}{r}21.33^{\star} \\
(11.86)\end{array}$ & $\begin{array}{l}37.05 \\
(26.11)\end{array}$ & $\begin{array}{c}36.10 \\
(23.70)\end{array}$ & $\begin{array}{c}35.68 \\
(23.61)\end{array}$ & $\begin{array}{c}68.21 \\
(48.80)\end{array}$ & $\begin{array}{l}65.10 \\
(48.21)\end{array}$ & $\begin{array}{c}62.52 \\
(47.87)\end{array}$ \\
\hline $\begin{array}{l}\text { Insurance } \\
\text { other }\end{array}$ & $\begin{array}{l}-36.32^{* t+} \\
(5.86)\end{array}$ & $\begin{array}{l}-41.75^{+1+t} \\
(5.86)\end{array}$ & $\begin{array}{l}-44.34 *+4 \\
(5.77)\end{array}$ & $\begin{array}{l}-70.13^{* * 4} \\
(11.72)\end{array}$ & $\begin{array}{l}-75.75^{*} \\
(11.52)\end{array}$ & $\begin{array}{l}-80.63 * * \hbar \\
(11.47)\end{array}$ & $\begin{array}{l}-136.9^{* * *} \\
(23.71)\end{array}$ & $\begin{array}{l}-142.9 * \\
(23.42)\end{array}$ & $\begin{array}{l}-148.2^{\star \star \star *} \\
(23.26)\end{array}$ \\
\hline $\begin{array}{l}\text { Benefit Formula } \\
\text { Dollar Anount }\end{array}$ & $\begin{array}{l}-52.32^{* 4 *} \\
(4.87)\end{array}$ & $\begin{array}{l}-41.02^{\star * \hbar} \\
(4.87)\end{array}$ & $\begin{array}{l}-31.61 * \ldots \\
(4.80)\end{array}$ & $\begin{array}{l}-119.7=6 . \\
(9.74)\end{array}$ & $\begin{array}{l}-108.5 * 1 \\
(9.57)\end{array}$ & $\begin{array}{l}-97.08=1 . \\
(9.54)\end{array}$ & $\begin{array}{l}-252.3^{*} \neq \\
(19.71)\end{array}$ & $\begin{array}{l}-241.5 * * \\
(19.47)\end{array}$ & $\begin{array}{l}-230.4 * * * \\
(19.33)\end{array}$ \\
\hline other & $\begin{array}{l}-52.24^{* k *} \\
(19.25)\end{array}$ & $\begin{array}{l}-61.08^{1 * k *} \\
(19.24)\end{array}$ & $\begin{array}{l}-67.67+* * \\
(18.92)\end{array}$ & $\begin{array}{l}-120^{k *} \\
(38.45)\end{array}$ & $\begin{array}{l}-129.1 * * \\
(37.79)\end{array}$ & $\begin{array}{l}-136.7 * * * \\
(37.65)\end{array}$ & $\begin{array}{l}-253.9 \pi \hbar \hbar \\
(77.82)\end{array}$ & $\begin{array}{l}-263.5^{\hbar \pi} \\
(76.87)\end{array}$ & $\begin{array}{l}-271.6 \pm \hbar \\
(76.33)\end{array}$ \\
\hline $\begin{array}{c}\text { Number of Employees } \\
1 \cdot 99\end{array}$ & $\begin{array}{l}-20.36 \\
(21.50)\end{array}$ & $\begin{array}{l}-12.35 \\
(21.49)\end{array}$ & $\begin{array}{l}-10.69 \\
(21.13)\end{array}$ & $\begin{array}{l}-46.19 \\
(42.96)\end{array}$ & $\begin{array}{l}-38.24 \\
(42.22)\end{array}$ & $\begin{array}{l}-38.52 \\
(42.07)\end{array}$ & $\begin{array}{l}-97.10 \\
(86.94)\end{array}$ & $\begin{array}{l}-89.28 \\
(85.89)\end{array}$ & $\begin{array}{l}-89.68 \\
(85.27)\end{array}$ \\
\hline $100=249$ & $\begin{array}{l}-19.43^{\hbar \hbar} \\
(8.67)\end{array}$ & $\begin{array}{l}-19.93^{* *} \\
(8.66)\end{array}$ & $\begin{array}{l}-20.20^{* *} \\
(8.52)\end{array}$ & $\begin{array}{l}-30.27^{\star} \\
(17.32)\end{array}$ & $\begin{array}{l}-31.15 * \\
(17.02)\end{array}$ & $\begin{array}{l}-32.12 * \\
(16.96)\end{array}$ & $\begin{array}{l}-50.59 \\
(35.04)\end{array}$ & $\begin{array}{l}.52 .23 \\
(34.62)\end{array}$ & $\begin{array}{l}-53.97 \\
(34.37)\end{array}$ \\
\hline $250-499$ & $\begin{array}{l}-11.35 \star \\
(5.83)\end{array}$ & $\begin{array}{l}-10.90 \\
(5.83)\end{array}$ & $\begin{array}{l}-11.61 * * \\
(5.73)\end{array}$ & $\begin{array}{l}-16.25 \\
(11.65)\end{array}$ & $\begin{array}{l}-16.09 \\
(11.45)\end{array}$ & $\begin{array}{l}-17.70 \\
(11.61)\end{array}$ & $\begin{array}{l}-25.01 \\
(23.58)\end{array}$ & $\begin{array}{l}-25.43 \\
(23.29)\end{array}$ & $\begin{array}{l}-27.62 \\
(23.13)\end{array}$ \\
\hline $\begin{array}{r}500-999 \\
1000-2499\end{array}$ & $\begin{array}{l}-13.87^{\star *} \\
(5.65) \\
(0.99 * * \\
(4.93)\end{array}$ & $\begin{array}{l}-16.46 t * t \\
(5.65) \\
7.78 \\
(4.93)\end{array}$ & $\begin{array}{l}-17.76 \text { *t. } \\
(5.56) \\
5.87 \\
(4.85)\end{array}$ & $\begin{array}{l}-20.23 \\
(11.29) \\
31.47 \cdots * \\
(9.85)\end{array}$ & $\begin{array}{l}-23.00 * \\
(11.09) \\
28.02^{* * *} \\
(9.68)\end{array}$ & $\begin{array}{l}-26.33^{* *} \\
(11.05) \\
24.55^{* *} \\
(9.65)\end{array}$ & $\begin{array}{l}-31.65 \\
(22.84) \\
73.83^{* * *} \\
(19.94)\end{array}$ & $\begin{array}{l}-34.82 \\
(22.56) \\
69.89 \\
(19.69)\end{array}$ & $\begin{array}{l}-38.55 \star \\
(22.40) \\
65.94 \approx * \\
(19.55)\end{array}$ \\
\hline $\begin{array}{l}\text { Net Assets } \\
\text { (millions) }\end{array}$ & $\begin{array}{l}20.89 k 1 k \\
(4.61)\end{array}$ & $\begin{array}{l}25.34 * t k \\
(4.61)\end{array}$ & $\begin{array}{l}34.24 * \hbar * \\
(4.55)\end{array}$ & $\begin{array}{c}37.25 * k * \\
(9.21)\end{array}$ & $\begin{array}{l}41.55^{* 4 *} \\
(9.06)\end{array}$ & $\begin{array}{l}46.58 * k k \\
(9.02)\end{array}$ & $\begin{array}{l}71.00^{\star \star \star *} \\
(18.65)\end{array}$ & $\begin{array}{l}75.02^{\star \star \star \star} \\
(18.42)\end{array}$ & $\begin{array}{l}79.76^{\star \star \star} \\
(18.29)\end{array}$ \\
\hline Sample Size & 651 & 651 & 649 & 651 & 651 & 651 & 651 & 651 & 651 \\
\hline Adjusted R2 & 0.35 & 0.33 & 0.40 & 0.39 & 0.36 & 0.35 & 0.61 & 0.39 & 0.37 \\
\hline Sample Mean Increase & 52 & 60 & 68 & 93 & 102 & 110 & 175 & 183 & 191 \\
\hline
\end{tabular}

"standard errors are in parentheses. Other control variables are the same os Table A1.

- Statistically different fron zero at that the .10 confidence level.

* Statistically different from zero at that the .05 confidence level

*** Statistically different from zero at that the .01 confidence level.

Source: watehed 1986 EBS-5500 file. 
Toble 13

Weighted Estimates of the Effects of Retiree and Firm Characterlstics on Post-Retirement Increases $1980-85$ Participante Retired in 1975 Receiving Incresses"

\begin{tabular}{|c|c|c|c|c|c|c|c|c|c|}
\hline & \multirow{2}{*}{\multicolumn{3}{|c|}{$\frac{\text { Pension of } \$ 250}{\text { Yegrs of Service }}$}} & \multicolumn{3}{|c|}{ Pension of $\$ 500$} & \multicolumn{3}{|c|}{ Pension of $\$ 1,000$} \\
\hline & & & & \multicolumn{3}{|c|}{ Years of Service } & \multicolumn{3}{|c|}{ Years of service } \\
\hline & 10 & 20 & $\overline{30}$ & 10 & 20 & 30 & 10 & 20 & 30 \\
\hline $\begin{array}{l}\text { Rate of Return } \\
\text { Missing }\end{array}$ & $\begin{array}{c}-3.29 \\
(9.19)\end{array}$ & $\begin{array}{l}9.11 \\
(9.43)\end{array}$ & $\left(\begin{array}{l}19.68 * 1 \% \\
(9.38)\end{array}\right.$ & $\begin{array}{l}-16.56 \\
(18.59)\end{array}$ & $\begin{array}{c}-6.22 \\
(18.19)\end{array}$ & $\begin{array}{c}8.08 \\
(18.29)\end{array}$ & $\begin{array}{l}-43.00 \\
(38.08)\end{array}$ & $\begin{array}{l}-30.83 \\
(37.37)\end{array}$ & $\begin{array}{l}-18.68 \\
(37.03)\end{array}$ \\
\hline $.11-.15$ & $\begin{array}{c}-3.41 \\
(14.86)\end{array}$ & $\begin{array}{c}-6.46 \\
(15.24)\end{array}$ & $\begin{array}{c}-8.48 \\
(15.16)\end{array}$ & $\begin{array}{c}0.81 \\
(30.06)\end{array}$ & $\begin{array}{c}-2.50 \\
(29.40)\end{array}$ & $\begin{array}{c}-5.11 \\
(29.56)\end{array}$ & $\begin{array}{c}9.01 \\
(61.57)\end{array}$ & $\begin{array}{c}5.18 \\
(60.42)\end{array}$ & $\begin{array}{c}2.05 \\
(59.88)\end{array}$ \\
\hline $.16=.20$ & $\begin{array}{c}-0.43 \\
(9.42)\end{array}$ & $\begin{array}{l}5.50 \\
(9.66)\end{array}$ & $\begin{array}{c}11.07 \\
(9.61)\end{array}$ & $\begin{array}{c}-5.12 \\
(19.05)\end{array}$ & $\begin{array}{c}0.90 \\
(18.64)\end{array}$ & $\begin{array}{c}7.86 \\
(18.74)\end{array}$ & $\begin{array}{l}-14.78 \\
(39.02)\end{array}$ & $\begin{array}{c}-8.58 \\
(38.30)\end{array}$ & $\begin{array}{c}-1.45 \\
(37.95)\end{array}$ \\
\hline $.21-.25$ & $\begin{array}{c}10.70 \\
(9.22)\end{array}$ & $\begin{array}{l}24.49^{* *} \\
(9.46)\end{array}$ & $\begin{array}{l}35.98^{4} \cdot 4 \\
(9.42)\end{array}$ & $\begin{array}{c}14.34 \\
(18.67)\end{array}$ & $\begin{array}{c}28.27 \\
(18.26)\end{array}$ & $\begin{array}{l}42.07 * \hbar \\
(18.36)\end{array}$ & $\frac{21.23}{(38.23)}$ & $\begin{array}{l}35.43 \\
(37.52)\end{array}$ & $\begin{array}{c}49.51 \\
(37.18)\end{array}$ \\
\hline$>.25$ & $\begin{array}{l}1.92 \\
(9.27)\end{array}$ & $\begin{array}{r}17.80 * \\
(9.51)\end{array}$ & $\begin{array}{l}27.64 * * * \\
(9.47)\end{array}$ & $\begin{array}{c}-9.66 \\
(18.77)\end{array}$ & $\begin{array}{c}6.36 \\
(18.35)\end{array}$ & $\begin{array}{c}20.95 \\
(18.45)\end{array}$ & $\begin{array}{l}-31.53 \\
(38.43)\end{array}$ & $\begin{array}{l}-15.91 \\
(37.72)\end{array}$ & $\begin{array}{c}-1.49 \\
(37.38)\end{array}$ \\
\hline $\begin{array}{l}\text { Funding Retio } \\
\text { (times 100) }\end{array}$ & $\left(\begin{array}{l}0.29 \cdots \cdots \\
0.06)\end{array}\right.$ & $\left(\begin{array}{l}0.19 * \\
0.06)\end{array}\right.$ & $\begin{array}{l}0.06 \\
(0.06)\end{array}$ & $\left(\begin{array}{l}0.69 * \text { * } \\
0.12)\end{array}\right.$ & $\left(\begin{array}{l}0.59 \\
0.12)\end{array}\right.$ & $\left(\begin{array}{l}0.49+ \pm t \\
0.12)\end{array}\right.$ & $\begin{array}{l}1.48^{\text {t+t }} \\
(0.25)\end{array}$ & $\left(\begin{array}{l}1.39 \% * \pi \\
0.25)\end{array}\right.$ & $\left(\begin{array}{l}1.29 * * \\
0.24)\end{array}\right.$ \\
\hline $\begin{array}{l}\text { Ratio of Recipients } \\
\text { to Participents }\end{array}$ & $\begin{array}{l}-52.58 * 4 \\
(15.06)\end{array}$ & $\begin{array}{l}-53.06 \% \pm \\
(15.65)\end{array}$ & $\begin{array}{l}-42.53 \\
(15.40)\end{array}$ & $\begin{array}{l}-76.21+4 \\
(30.40)\end{array}$ & $\begin{array}{l}-77.44 \% \\
(29.81)\end{array}$ & $\begin{array}{l}-77.18^{\star *} \\
(29.97)\end{array}$ & $\begin{array}{l}-924.2^{\star t} \\
(62.43)\end{array}$ & $\begin{array}{c}-127 \\
(61.26)\end{array}$ & $\begin{array}{l}-128.3 * * \\
(60.71)\end{array}$ \\
\hline $\begin{array}{l}\text { Fund Arrangement } \\
\text { Insurance }\end{array}$ & $\left(\begin{array}{l}6.33 \\
8.26\end{array}\right)$ & $\begin{array}{l}5.76 \\
(8.48)\end{array}$ & $\begin{array}{c}4.57 \\
(8.64)\end{array}$ & $\begin{array}{c}8.59 \\
(16.72)\end{array}$ & $\begin{array}{c}6.95 \\
(16.36)\end{array}$ & $\begin{array}{c}5.85 \\
(16.44)\end{array}$ & $\begin{array}{c}12.68 \\
(34.25)\end{array}$ & $\begin{array}{c}8.88 \\
(33.61)\end{array}$ & $\begin{array}{c}5.62 \\
(33.31)\end{array}$ \\
\hline $\begin{array}{l}\text { Insurance } \boldsymbol{t} \text { Trusts, } \\
\text { Other }\end{array}$ & $\begin{array}{l}-23.46^{* * \hbar} \\
(4.01)\end{array}$ & $\begin{array}{l}-28.87 \\
(4.12)\end{array}$ & $\begin{array}{l}-31.51^{*+}= \\
(4.10)\end{array}$ & $\begin{array}{l}+63.97 \%+ \\
(8.12)\end{array}$ & $\begin{array}{l}-49.58 * 1 \\
(7.95)\end{array}$ & $\begin{array}{l}*-54.44 * * * \\
(7.99)\end{array}$ & $\begin{array}{l}-85.07^{* * *} \\
(16.64)\end{array}$ & $\begin{array}{l}-91.07 * * * \\
(16.33)\end{array}$ & $\begin{array}{l}-96.33^{* \star *} \\
(16.18)\end{array}$ \\
\hline $\begin{array}{l}\text { Benefit formula } \\
\text { Dollar Anount }\end{array}$ & $\begin{array}{l}-28.73^{* *} \\
(3.31)\end{array}$ & $\begin{array}{l}-17,90 \% \\
(3.40)\end{array}$ & $\left(\begin{array}{l}-8.7901 \% \\
(3.39)\end{array}\right.$ & $\begin{array}{l}-72.64 * 4 \% \\
(0.71)\end{array}$ & $\begin{array}{l}-61.97 \ldots+1 \\
(6.56)\end{array}$ & $\begin{array}{l}.50 .96 * * \hbar \\
(6.59)\end{array}$ & $\begin{array}{l}-159.1 * \pm \\
(13.73)\end{array}$ & $\begin{array}{l}-148.8^{+1 *} \\
(13.48)\end{array}$ & $\begin{array}{l}-138.1^{* * *} \\
(13.36)\end{array}$ \\
\hline Other & $\begin{array}{l}-28.29 * * \\
(13.18)\end{array}$ & $\begin{array}{l}-37.00 \text { the } \\
(13.52)\end{array}$ & $\begin{array}{l}-43.52 \% 1+4 \\
(13.45)\end{array}$ & $\begin{array}{l}-73.07 \%= \\
(26.66)\end{array}$ & $\begin{array}{l}-82.04=11 \\
(26.08)\end{array}$ & $\begin{array}{l}-89.48^{* * *} \\
(26.22)\end{array}$ & $\begin{array}{l}-161.3 \cdots * \hbar \\
(54.61)\end{array}$ & $\begin{array}{l}-170.8 \hbar \hbar \hbar \\
(53.59)\end{array}$ & $\begin{array}{l}-178.7^{* \pi t} \\
(53.10)\end{array}$ \\
\hline $\begin{array}{c}\text { Number of Employees } \\
1 \cdot 99\end{array}$ & $\begin{array}{l}-10.44 \\
(14.71)\end{array}$ & $\begin{array}{c}-1.58 \\
(15.09)\end{array}$ & $\begin{array}{c}0.73 \\
(15.02)\end{array}$ & $\begin{array}{l}-29.96 \\
(29.77)\end{array}$ & $\begin{array}{l}-21.13 \\
(29.12)\end{array}$ & $\begin{array}{l}-20.61 \\
(29.28)\end{array}$ & $\begin{array}{l}-68.59 \\
(60.97)\end{array}$ & $\begin{array}{l}-59.89 \\
(59.83)\end{array}$ & $\begin{array}{l}-59.49 \\
(59.29)\end{array}$ \\
\hline $100 \cdot 249$ & $\begin{array}{l}-12.49+1 \\
(5.92)\end{array}$ & $\begin{array}{l}-12.54 * * \\
(6.07)\end{array}$ & $\begin{array}{l}-12.51 * 4 \\
(6.06)\end{array}$ & $\begin{array}{l}-20.06^{*} \\
(11.98)\end{array}$ & $\begin{array}{l}-20.69 \\
(11.71)\end{array}$ & $\begin{array}{l}-21.06 * \\
(11.78)\end{array}$ & $\begin{array}{l}-35.93 \\
(24.53)\end{array}$ & $\begin{array}{l}-37.11 \\
(24.07)\end{array}$ & $\begin{array}{l}-38.44 \\
(23.85)\end{array}$ \\
\hline $250 \cdot 499$ & $\begin{array}{c}-4.68 \\
(3.99)\end{array}$ & $\begin{array}{c}-3.98 \\
(4.09)\end{array}$ & $\begin{array}{c}-4.51 \\
(4.07)\end{array}$ & $\left(\begin{array}{l}-6.75 \\
0.07)\end{array}\right.$ & $\begin{array}{c}-6.36 \\
(7.90)\end{array}$ & $\begin{array}{c}-7.71 \\
(7.94)\end{array}$ & $\begin{array}{l}-10.81 \\
(16.53)\end{array}$ & $\begin{array}{l}-10.97 \\
(16.23)\end{array}$ & $\begin{array}{l}-12.92 \\
(16.08)\end{array}$ \\
\hline $500 \cdot 999$ & $\begin{array}{r}-7.31 * \\
(3.87)\end{array}$ & $\begin{array}{c}-9.85^{\star *} \\
(3.97)\end{array}$ & $\begin{array}{l}-11.16^{* 4 *} \\
(3.95)\end{array}$ & $\begin{array}{c}-10.72 \\
(7.82)\end{array}$ & $\begin{array}{l}-13.46 \\
(7.65)\end{array}$ & $\begin{array}{l}-16.76^{\star *} \\
(7.69)\end{array}$ & $\begin{array}{l}-16.89 \\
(16.03)\end{array}$ & $\begin{array}{l}-20.03 \\
(15.73)\end{array}$ & $\begin{array}{l}-23.73 \\
(15.59)\end{array}$ \\
\hline $1000 \cdot 2499$ & $\begin{array}{l}12.80^{* * *} \\
(3.35)\end{array}$ & $\begin{array}{l}9.27^{m+1 *} \\
(3.64)\end{array}$ & $\begin{array}{l}7.16^{t t} \\
3.62)\end{array}$ & $\begin{array}{l}33.42^{1+k} \\
(6.78)\end{array}$ & $\begin{array}{l}29.65 * * * \\
(6.63)\end{array}$ & $\begin{array}{l}25.92^{* * 4} \\
(6.67)\end{array}$ & $\begin{array}{l}74.14^{* * *} \\
(13.88)\end{array}$ & $\begin{array}{l}69.89+4 \\
(13.63)\end{array}$ & $\begin{array}{l}65.67^{* * *} \\
(13.50)\end{array}$ \\
\hline $\begin{array}{l}\text { Het Assets } \\
\text { (millions) }\end{array}$ & $\left(\begin{array}{l}13.60 * \ldots \\
3.14)\end{array}\right.$ & $\left(\begin{array}{l}98.49+m \\
3.22)\end{array}\right.$ & $\begin{array}{l}27.65 * 4 \\
(3.22)\end{array}$ & $\frac{23.32^{* * * * t}}{(6.35)}$ & $\begin{array}{l}20.07+4 t \\
(6.21)\end{array}$ & $\begin{array}{l}+33.51 * \\
(6.24)\end{array}$ & $\begin{array}{l}42.34^{\star t \star} \\
(13.01)\end{array}$ & $\begin{array}{l}46.81^{* * m} \\
(12.76)\end{array}$ & $\begin{array}{l}51.97=0 . \\
(12.65)\end{array}$ \\
\hline Sample size & 657 & 657 & 655 & 657 & 657 & 657 & 657 & 657 & 657 \\
\hline Adjusted R2 & 0.38 & 0.39 & 0.52 & 0.43 & 0.40 & 0.39 & 0.45 & 0.43 & 0.41 \\
\hline Sample Mean Increase & 44 & 52 & 60 & 78 & 86 & 94 & 146 & 154 & 162 \\
\hline
\end{tabular}

"Standard errors are in parentheses. Dther control variables ore the same os Table Al.

* Statistically different from zero ot that the . 10 confidence level.

* Statistically different from zero ot that the .05 confidence level.

th Statistically different from zero ot that the .01 confidence level.

Source: Matched 1986 EBS-5500 file. 
Toble 14

Weighted Estimates of the Effects of Retiree and Fim Characteristics on Post-Retirement Increases 1980-85 Participants Retired in 1980 Receiving Increases"

\begin{tabular}{|c|c|c|c|c|c|c|c|c|c|}
\hline & \multicolumn{3}{|c|}{ Pension of $\$ 250$} & \multicolumn{3}{|c|}{ Pension of $\$ 500$} & \multicolumn{3}{|c|}{ Pension of $\$ 1,000$} \\
\hline & \multirow{2}{*}{\multicolumn{3}{|c|}{$\frac{\text { Years of Service }}{10} \frac{20}{30}$}} & \multicolumn{3}{|c|}{ Yesors of Service } & \multicolumn{3}{|c|}{ - Years of Service } \\
\hline & & & & 10 & 20 & 30 & 10 & 20 & 30 \\
\hline $\begin{array}{l}\text { Rate of Return } \\
\text { Missing }\end{array}$ & $\left(\begin{array}{l}5.23 \\
5.78)\end{array}\right.$ & $\left(7.177^{* *}\right.$ & $\begin{array}{l}28.50 * * * \\
(7.82)\end{array}$ & $\begin{array}{c}0.35 \\
(10.99)\end{array}$ & $\begin{array}{c}12.82 \\
(11.46)\end{array}$ & $\begin{array}{l}25.26^{* t} \\
(12.54)\end{array}$ & $\begin{array}{l}-8.90 \\
(22.11)\end{array}$ & $\begin{array}{c}3.42 \\
(22.12)\end{array}$ & $\begin{array}{c}15.72 \\
(22.62)\end{array}$ \\
\hline $.11 \cdot .15$ & $\left(\begin{array}{l}5.52 \\
(9.34)\end{array}\right.$ & $\begin{array}{c}1.15 \\
(11.48)\end{array}$ & $\begin{array}{l}-2.18 \\
(12.64)\end{array}$ & $\begin{array}{c}19.42 \\
(17.77)\end{array}$ & $\begin{array}{c}14.80 \\
(18.53)\end{array}$ & $\begin{array}{c}10.88 \\
(20.28)\end{array}$ & $\begin{array}{l}47.50 \\
(35.75)\end{array}$ & $\begin{array}{c}42.36 \\
(35.77)\end{array}$ & $\begin{array}{c}37.92 \\
(36.57)\end{array}$ \\
\hline $.16 \cdot .20$ & $\begin{array}{c}-7.92 \\
(5.92)\end{array}$ & $\begin{array}{c}-1.94 \\
(7.27)\end{array}$ & $\begin{array}{l}3.69 \\
(8.01)\end{array}$ & $\begin{array}{l}-18.81^{*} \\
(11.26)\end{array}$ & $\begin{array}{l}-12.75 \\
(11.74)\end{array}$ & $\begin{array}{l}-5.74 \\
(12.85)\end{array}$ & $\begin{array}{l}-40.82^{*} \\
(22.66)\end{array}$ & $\begin{array}{l}-34.58 \\
(22.67)\end{array}$ & $\begin{array}{l}-27.40 \\
(23.18)\end{array}$ \\
\hline $.21 \cdot .25$ & $\begin{array}{c}10.30^{*} \\
(5.80)\end{array}$ & $\begin{array}{l}24.90 * * * \\
(7.12)\end{array}$ & $\begin{array}{l}37.20^{\text {*** }} \\
(7.85)\end{array}$ & $\begin{array}{l}10.31 \\
(11.04)\end{array}$ & $\begin{array}{l}25.03^{\star \star} \\
(11.51)\end{array}$ & $\begin{array}{l}39.64 * \pm \hbar \\
(12.59)\end{array}$ & $\begin{array}{c}10.87 \\
(22.20)\end{array}$ & $\begin{array}{c}25.87 \\
(22.21)\end{array}$ & $\begin{array}{r}40.74 * \\
(22.71)\end{array}$ \\
\hline$>.25$ & $\left(\begin{array}{l}8.02 \\
(5.83)\end{array}\right.$ & $\left(\begin{array}{l}24.02 \text { *n: } \\
(7.16)\end{array}\right.$ & $\begin{array}{l}34.01^{* k *} \\
(7.90)\end{array}$ & $\begin{array}{c}0.47 \\
(11.09)\end{array}$ & $\begin{array}{c}16.38 \\
(11.57)\end{array}$ & $\begin{array}{l}31.09 * * \\
(12.66)\end{array}$ & $\begin{array}{l}-13.86 \\
(22.32)\end{array}$ & $\begin{array}{c}1.87 \\
(22.33)\end{array}$ & $\begin{array}{l}16.41 \\
(22.83)\end{array}$ \\
\hline $\begin{array}{l}\text { Funding Ratio } \\
\text { (times } 100)\end{array}$ & $\left(\begin{array}{l}0.10^{* * *} \\
(0.04)\end{array}\right.$ & $\left(\begin{array}{l}0.02 \\
0.05)\end{array}\right.$ & $\begin{array}{c}-0.10^{*} \\
(0.05)\end{array}$ & $\left(\begin{array}{l}0.30^{* k *} \\
0.07)\end{array}\right.$ & $\begin{array}{l}0.21^{* \pi *} \\
(0.08)\end{array}$ & $\begin{array}{l}0.12 \\
(0.08)\end{array}$ & $\begin{array}{l}0.69+\ldots \hbar \\
(0.94)\end{array}$ & $\left(\begin{array}{l}0.61 \star \star \star \\
(0.15)\end{array}\right.$ & $\left(\begin{array}{l}0.52^{\star * t} \\
0.15)\end{array}\right.$ \\
\hline $\begin{array}{l}\text { Ratio of Recipients } \\
\text { to Porticipants }\end{array}$ & $\begin{array}{l}-31.86 * * * \\
(9.47)\end{array}$ & $\begin{array}{l}-22.85 * \star \\
(11.63)\end{array}$ & $\begin{array}{c}-2.95 \\
(12.84)\end{array}$ & $\begin{array}{l}-57.28 * * \hbar \\
(18.02)\end{array}$ & $\begin{array}{l}-49.04=64 \\
(18.79)\end{array}$ & $\begin{array}{l}-39.31 * \\
(20.56)\end{array}$ & $\begin{array}{l}-110.9 * * * x \\
(36.25)\end{array}$ & $\begin{array}{l}-10 \% .2 * \hbar * \\
(36.27)\end{array}$ & $\begin{array}{l}-96.02^{\star \star \star *} \\
(37.08)\end{array}$ \\
\hline $\begin{array}{l}\text { Fund Arrangement } \\
\text { Insurance }\end{array}$ & $\begin{array}{c}-2.95 \\
(5.19)\end{array}$ & $\begin{array}{l}-4.36 \\
(6.38)\end{array}$ & $\begin{array}{c}-6.40 \\
(7.03)\end{array}$ & $\begin{array}{c}-6.01 \\
(9.89)\end{array}$ & $\begin{array}{c}-8.51 \\
(10.31)\end{array}$ & $\begin{array}{l}-10.46 \\
(11.28)\end{array}$ & $\begin{array}{l}-11.93 \\
(19.89)\end{array}$ & $\begin{array}{l}-16.59 \\
(19.90)\end{array}$ & $\begin{array}{l}-20.70 \\
(20.34)\end{array}$ \\
\hline $\begin{array}{l}\text { Insurance } \\
\text { other }\end{array}$ & $\begin{array}{l}-14.35 * \pm \\
(2.52)\end{array}$ & $\begin{array}{l}-20.19 * * \\
(3.10)\end{array}$ & $\begin{array}{l}-23.26^{* 4 *} \\
(3.42)\end{array}$ & $\begin{array}{l}-21.00 * * * \\
(4.80)\end{array}$ & $\begin{array}{l}-27.03 \pm \pm t \\
(5.01)\end{array}$ & $\begin{array}{l}-32.32^{\star \star \star} \\
(5.48)\end{array}$ & $\begin{array}{l}-35.46 * t * \\
(9.66)\end{array}$ & $\begin{array}{l}-41.89 * * \\
(9.67)\end{array}$ & $\begin{array}{l}-47.57 * * \\
(9.88)\end{array}$ \\
\hline $\begin{array}{l}\text { Benefit Formula } \\
\text { Dollar Amount }\end{array}$ & $\begin{array}{c}-4.42^{* \star} \\
(2.08)\end{array}$ & $\begin{array}{l}5.52^{\star \star} \\
(2.56)\end{array}$ & $\begin{array}{l}13.73^{* * \star} \\
(2.82)\end{array}$ & $\begin{array}{l}-22.82^{* 4 *} \\
(3.96)\end{array}$ & $\begin{array}{l}-13.06 * * * \\
(4.13)\end{array}$ & $\begin{array}{c}-2.94 \\
(4.52)\end{array}$ & $\begin{array}{l}-59.70 * * \star \\
(7.97)\end{array}$ & $\begin{array}{l}-50.28 * \star \star \\
(7.98)\end{array}$ & $\begin{array}{l}-40.50^{\star k \star} \\
(8.16)\end{array}$ \\
\hline other & $\left(\begin{array}{c}-0.37 \\
(8.28)\end{array}\right.$ & $\begin{array}{l}-11.13 \\
(10.18)\end{array}$ & $\begin{array}{l}-19.70^{*} \\
(11.21)\end{array}$ & $\begin{array}{l}-12.34 \\
(15.76)\end{array}$ & $\begin{array}{l}-23.36 \\
(16.43)\end{array}$ & $\begin{array}{l}-32.86 * \\
(17.99)\end{array}$ & $\begin{array}{l}-36.59 \\
(31.71)\end{array}$ & $\begin{array}{l}-48.13 \\
(31.72)\end{array}$ & $\begin{array}{l}-58.14 * \\
(32.43)\end{array}$ \\
\hline $\begin{array}{c}\text { Number of Employees } \\
1-99\end{array}$ & $\begin{array}{c}12.65 \\
(9.25)\end{array}$ & $\begin{array}{r}21.99 \\
(11.36)\end{array}$ & $\begin{array}{l}24.77 * * \\
(12.52)\end{array}$ & $\begin{array}{c}12.24 \\
(17.60)\end{array}$ & $\begin{array}{c}21.53 \\
(18.35)\end{array}$ & $\begin{array}{c}22.53 \\
(20.08)\end{array}$ & $\begin{array}{c}11.08 \\
(35.40)\end{array}$ & $\begin{array}{c}20.26 \\
(35.42)\end{array}$ & $\begin{array}{l}21.15 \\
(36.21)\end{array}$ \\
\hline $100-249$ & $\left(\begin{array}{l}0.19 \\
3.72)\end{array}\right.$ & $\left(\begin{array}{l}0.24 \\
(4.57)\end{array}\right.$ & $\left(\begin{array}{l}0.38 \\
(5.04)\end{array}\right.$ & $\begin{array}{l}0.78 \\
(7.08)\end{array}$ & $\begin{array}{l}0.45 \\
(7.38)\end{array}$ & $\begin{array}{c}-0.01 \\
(8.08)\end{array}$ & $\begin{array}{c}2.23 \\
(14.24)\end{array}$ & $\begin{array}{c}1.15 \\
(14.25)\end{array}$ & $\begin{array}{c}-0.07 \\
(14.57)\end{array}$ \\
\hline $250-499$ & $\begin{array}{l}1.98 \\
(2.51)\end{array}$ & $\left(\begin{array}{l}2.08 \\
(3.08)\end{array}\right.$ & $\begin{array}{l}0.95 \\
(3.40)\end{array}$ & $\left(\begin{array}{l}3.00 \\
(4.77)\end{array}\right.$ & $\begin{array}{l}2.81 \\
(4.98)\end{array}$ & $\left(\begin{array}{l}0.84 \\
(5.45)\end{array}\right.$ & $\begin{array}{l}5.23 \\
(9.60)\end{array}$ & $\begin{array}{l}4.47 \\
(9.61)\end{array}$ & $\left(\begin{array}{l}1.92 \\
(9.82)\end{array}\right.$ \\
\hline $500-999$ & $\begin{array}{c}-3.40 \\
(2.43)\end{array}$ & $\begin{array}{l}-6.76 * 4 \\
(2.99)\end{array}$ & $\begin{array}{l}-8.88 * 4 * \\
(3.29)\end{array}$ & $\begin{array}{c}-4.78 \\
(4.63)\end{array}$ & $\begin{array}{r}-8.33^{*} \\
(4.82)\end{array}$ & $\begin{array}{l}-12.44=6 \\
(5.28)\end{array}$ & $\begin{array}{c}-7.85 \\
(9.31)\end{array}$ & $\begin{array}{l}-11.80 \\
(9.31)\end{array}$ & $\begin{array}{l}-16.31 \star \\
(9.52)\end{array}$ \\
\hline $1000-2499$ & $\begin{array}{l}7.69 * * * \\
(2.11)\end{array}$ & $\begin{array}{l}3.73 \\
(2.59)\end{array}$ & $\begin{array}{l}1.16 \\
(2.85)\end{array}$ & $\begin{array}{l}21.13^{* * 4} \\
(4.01)\end{array}$ & $\begin{array}{l}16.92^{* * *} \\
(4.18)\end{array}$ & $\begin{array}{l}12.7^{\hbar t \pi} \\
(4.57)\end{array}$ & $\begin{array}{l}48.03^{* k *} \\
(8.06)\end{array}$ & $\begin{array}{l}43.33 * \ldots \\
(8.07)\end{array}$ & $\begin{array}{l}38.66 * * * \\
(8.25)\end{array}$ \\
\hline $\begin{array}{l}\text { Net Assets } \\
\text { (millions) }\end{array}$ & $\begin{array}{l}8.98^{+4 *} \\
(1.97)\end{array}$ & $\begin{array}{l}12.6)^{* \hbar \hbar \hbar} \\
(2.42)\end{array}$ & $\begin{array}{l}20.484 \pm t \\
(2.68)\end{array}$ & $\left(\begin{array}{l}17.00 * * t \\
3.75)\end{array}\right.$ & $\begin{array}{l}20.49=\ldots \\
(3.91)\end{array}$ & $\begin{array}{l}24.67 \%=6 \\
(4.28)\end{array}$ & $\begin{array}{l}32.666^{* * *} \\
(7.55)\end{array}$ & $\begin{array}{c}35.87^{* 1 * \hbar} \\
(7.56)\end{array}$ & $\begin{array}{l}39.78^{* * *} \\
(7.72)\end{array}$ \\
\hline Sample size & 657 & 657 & 655 & 657 & 657 & 657 & 657 & 657 & 657 \\
\hline Adjusted R2 & 0.46 & 0.52 & 0.65 & 0.48 & 0.46 & 0.48 & 0.52 & 0.48 & 0.46 \\
\hline Sample Mean Increase & 28 & 37 & 44 & 46 & 55 & 63 & 83 & 92 & 900 \\
\hline
\end{tabular}

"Standard errors are in parentheses. Other control variables are the same as rable A1.

* Statistically different from zero at that the .10 confidence level.

* Statistically different from zero at that the .05 confidence level.

*** statistically different from zero at that the .01 confidence ievel.

Source: Matched 1986 EBS-5500 file. 